\title{
Potential intestinal infection and faecal-oral transmission of SARS-CoV-2
}

\author{
Meng Guo (D), Wanyin Tao, Richard A. Flavell(D) and Shu Zhu(D)
}

Abstract | Severe acute respiratory syndrome coronavirus 2 (SARS-CoV-2) has spread to more than 200 countries and regions globally. SARS-CoV-2 is thought to spread mainly through respiratory droplets and close contact. However, reports have shown that a notable proportion of patients with coronavirus disease 2019 (COVID-19) develop gastrointestinal symptoms and nearly half of patients confirmed to have COVID-19 have shown detectable SARS-CoV-2 RNA in their faecal samples. Moreover, SARS-CoV-2 infection reportedly alters intestinal microbiota, which correlated with the expression of inflammatory factors. Furthermore, multiple in vitro and in vivo animal studies have provided direct evidence of intestinal infection by SARS-CoV-2. These lines of evidence highlight the nature of SARS-CoV-2 gastrointestinal infection and its potential faecal-oral transmission. Here, we summarize the current findings on the gastrointestinal manifestations of COVID-19 and its possible mechanisms. We also discuss how SARS-CoV-2 gastrointestinal infection might occur and the current evidence and future studies needed to establish the occurrence of faecal-oral transmission.

Coronaviruses belong to the Coronaviridae family of the order Nidovirales ${ }^{1}$. They are positive-sense strand RNA viruses with $\sim 30 \mathrm{~kb}$ RNA genomes and an envelope with surface 'spikes'. Historically, these viruses have not been considered highly pathogenic to humans because they cause only mild, self-limiting respiratory infections, that is, until the outbreak of severe acute respiratory syndrome (SARS) in 2002 (REF. ${ }^{2}$ ). In December 2019, an outbreak of severe acute respiratory syndrome coronavirus 2 (SARS-CoV-2) infection was reported in several hospitals in Wuhan (Hubei Province, China $)^{3}$. Since then, the virus has infected $>105$ million people as of 8 February 2021, spreading to over 200 countries or regions worldwide $^{4}$ and is the causative agent of the ongoing coronavirus disease 2019 (COVID-19) pandemic.

There are three highly pathogenic coronaviruses, namely SARS-CoV, Middle East respiratory syndrome coronavirus $(\mathrm{MERS}-\mathrm{CoV})^{1}$ and SARS-CoV-2 (REF. ${ }^{3}$ ), which belong to the Betacoronavirus genus. They mainly infect the respiratory tract through attachment to the angiotensinconverting enzyme 2 (ACE2) receptor (SARS-CoV and SARS-CoV-2) or dipeptidyl peptidase 4 (DPP4) receptor (MERS-CoV) $)^{1,5}$. After entry, SARS-CoV, MERS-CoV and SARS-CoV-2 infections only induce a low or delayed interferon response ${ }^{6-8}$. As a consequence, the rapid viral replication triggers the release of pro-inflammatory cytokines and/or chemokines and massive infiltration of inflammatory cells ${ }^{6,7}$. These events, in severe cases, lead to acute lung injury and acute respiratory distress syndrome, which are the leading causes of death during SARS-CoV-2 infection'.

According to a report of 72,314 cases in China, the overall case-fatality rate was $2.3 \%{ }^{10}$. Mild to moderate disease, which was considered as non-pneumonia and mild pneumonia, was reported in $81 \%$ of cases $^{10}$. Meanwhile, severe (that is, dyspnoea, respiratory frequency $\geq 30$ breaths per minute, blood oxygen saturation $\leq 93 \%$, partial pressure of arterial oxygen to fraction of inspired oxygen ratio $<300$, and/or lung infiltrates $>50 \%$ within $24-48$ hours) and critical (that is, respiratory failure, septic shock, and/or multiple organ dysfunction or failure) disease were reported in $14 \%$ and $5 \%$ of cases, respectively ${ }^{10}$. On admission, the most common symptoms were cough $(67.8 \%)$ and fever $(43.8 \%)^{11}$ and ground-glass opacity was the most common radiological finding on chest $\mathrm{CT}^{12}$.

Most studies have focused on SARS-CoV-2 infection and clinical symptoms in the respiratory tract. However, ACE2 is also highly expressed in the intestine $\mathrm{e}^{13,14}$. According to a meta-analysis of data from a Hong Kong cohort published in $2020,17.6 \%$ of patients with COVID-19 have gastrointestinal symptoms ${ }^{15}$ and $48.1 \%$ of faecal samples from patients with COVID-19 have tested positive for viral RNA $^{15}$. Potential gastrointestinal infection and faecal-oral transmission should therefore be carefully considered.

In this Perspective, we summarize the gastrointestinal manifestations of COVID-19 and the possible underlying mechanisms, the current lines of evidence showing intestinal infection, and the in vitro and in vivo models that are being used to study SARS-CoV-2 intestinal infection. Additionally, we discuss the possible influence of intestinal infection on the immune response that might contribute to the so-called cytokine release syndrome (CRS), also known as 'cytokine storm', during viral pneumonia. Moreover, we discuss the remaining questions that need to be resolved surrounding SARS-CoV-2 intestinal infection and its potential faecal-oral transmission to stimulate the desperately needed research on this topic to improve our understanding of this pandemic.

\section{Gastrointestinal symptoms in COVID-19} Multiple studies have reported gastrointestinal symptoms in patients with COVID-19. Diarrhoea, nausea, vomiting, anorexia and abdominal pain are described as the main gastrointestinal symptoms in most studies, although other gastrointestinal symptoms, such as acid reflux, upper gastrointestinal bleeding, haematochezia, constipation and melena, have also been reported in a few cases $^{11,16-29}$ (TABLE 1). According to a meta-analysis that included 10,890 patients, the pooled prevalence 
Table 1 | Studies reporting proportion of patients with COVID-19 with gastrointestinal symptoms

\begin{tabular}{|c|c|c|c|c|c|c|}
\hline Study & Region & Time & $\begin{array}{l}\text { Total } \\
\text { number of } \\
\text { patients }\end{array}$ & Gastrointestinal symptom & $\begin{array}{l}\text { Point at which } \\
\text { symptoms } \\
\text { were reported }\end{array}$ & $\begin{array}{l}\text { Gastrointestinal } \\
\text { symptoms and disease } \\
\text { severity }\end{array}$ \\
\hline \multicolumn{7}{|c|}{ Studies in adults } \\
\hline Lin et al. ${ }^{25}$ & Zhuhai, China & $\begin{array}{l}17 \text { Jan to } \\
15 \text { Feb } 2020\end{array}$ & 95 & $\begin{array}{l}\text { Diarrhoea } 18.9 \% \text {; nausea } \\
14.7 \% \text {; vomiting } 4.2 \% \text {; anorexia } \\
12.6 \% \text {; acid reflux } 1.1 \% \text {; } \\
\text { epigastric discomfort } 2.1 \%\end{array}$ & $\begin{array}{l}\text { During } \\
\text { hospitalization }\end{array}$ & $\begin{array}{l}\text { No statistically significant } \\
\text { difference in the clinical } \\
\text { outcomes (remained in } \\
\text { hospital, discharged or died) }\end{array}$ \\
\hline \multirow[t]{2}{*}{ Papa et al..$^{27, a}$} & \multirow[t]{2}{*}{ Rome, Italy } & \multirow[t]{2}{*}{$\begin{array}{l}15 \text { Mar to } \\
14 \text { Apr } 2020\end{array}$} & \multirow[t]{2}{*}{34} & $\begin{array}{l}\text { Any gastrointestinal } \\
\text { symptoms } 8.8 \%\end{array}$ & On admission & \multirow{2}{*}{$\begin{array}{l}\text { Gastrointestinal symptoms } \\
\text { associated with reduced } \\
\text { mortality }\end{array}$} \\
\hline & & & & $\begin{array}{l}\text { Any gastrointestinal } \\
\text { symptoms } 32.3 \%\end{array}$ & $\begin{array}{l}\text { During } \\
\text { hospitalization }\end{array}$ & \\
\hline Chen et al. ${ }^{24, a}$ & Baltimore, USA & $\begin{array}{l}9 \text { Mar to } \\
15 \text { Apr } 2020\end{array}$ & 101 & $\begin{array}{l}\text { Diarrhoea } 50 \% \text {; nausea } 30 \% \text {; } \\
\text { vomiting } 14 \% \text {; abdominal } \\
\text { pain } 26 \% \text {; anorexia } 53 \% \text {; } \\
\text { haematochezia } 1 \%\end{array}$ & On admission & $\begin{array}{l}\text { No correlation between } \\
\text { gastrointestinal } \\
\text { symptoms and increased } \\
\text { hospitalization rate or } \\
\text { ICU care needs }\end{array}$ \\
\hline Ferm et al. ${ }^{17}$ & New York, USA & $\begin{array}{l}14 \text { Mar to } \\
1 \text { Apr } 2020\end{array}$ & 892 & $\begin{array}{l}\text { Diarrhoea } 9.8 \% \text {; nausea } \\
16.6 \% \text {; vomiting } 10.2 \% \text {; loss } \\
\text { of taste } 2.4 \% \text {; loss of appetite } \\
11.8 \% \text {; abdominal pain } 7.8 \%\end{array}$ & On admission & $\begin{array}{l}\text { No difference in ICU } \\
\text { admission, length of stay, } \\
\text { or mortality }\end{array}$ \\
\hline $\begin{array}{l}\text { Remes-Troche } \\
\text { et al. }{ }^{20}\end{array}$ & Veracruz, Mexico & $\begin{array}{l}1 \text { Apr to } \\
5 \text { May } 2020\end{array}$ & 112 & $\begin{array}{l}\text { Diarrhoea 7.8\%; vomiting } \\
\text { 7.1\%; abdominal pain } 9.8 \%\end{array}$ & On admission & $\begin{array}{l}\text { No statistically significant } \\
\text { difference in disease severity }\end{array}$ \\
\hline Wan et al. ${ }^{28}$ & China & $\begin{array}{l}19 \text { Jan to } \\
6 \text { Mar } 2020\end{array}$ & 232 & $\begin{array}{l}\text { Diarrhoea } 21 \% \text {; abdominal } \\
\text { pain } 1 \% \text {; bloody stool } 4 \%\end{array}$ & $\begin{array}{l}\text { During } \\
\text { hospitalization }\end{array}$ & $\begin{array}{l}\text { Gastrointestinal symptoms } \\
\text { associated with severe } \\
\text { symptoms of pneumonia }\end{array}$ \\
\hline Díaz et al. ${ }^{18}$ & Chile & $\begin{array}{l}\text { Until } 11 \text { Apr } \\
2020\end{array}$ & 7,016 & $\begin{array}{l}\text { Diarrhoea } 7.3 \% \text {; abdominal } \\
\text { pain } 3.7 \%\end{array}$ & $\begin{array}{l}\text { No distinction } \\
\text { made }\end{array}$ & $\begin{array}{l}\text { Gastrointestinal symptoms } \\
\text { associated with a higher risk } \\
\text { of hospitalization }\end{array}$ \\
\hline $\begin{array}{l}\text { Cholankeril } \\
\text { et al. } .^{29}\end{array}$ & California, USA & $\begin{array}{l}\text { 4 Mar to } \\
24 \text { Mar } 2020\end{array}$ & 116 & $\begin{array}{l}\text { Diarrhoea } 10.3 \% \text {; nausea } \\
\text { and/or vomiting } 10.3 \% \text {; } \\
\text { abdominal pain } 8.8 \% \text {; } \\
\text { loss of appetite } 25.3 \%\end{array}$ & $\begin{array}{l}\text { No distinction } \\
\text { made }\end{array}$ & $\begin{array}{l}\text { No correlation between } \\
\text { gastrointestinal symptoms } \\
\text { and disease severity }\end{array}$ \\
\hline $\begin{array}{l}\text { Hajifathalian } \\
\text { et al. }^{21}\end{array}$ & New York, USA & $\begin{array}{l}4 \text { Mar to } \\
9 \text { Apr } 2020\end{array}$ & 1,059 & $\begin{array}{l}\text { Diarrhoea 22\%; abdominal } \\
\text { pain } 7 \%\end{array}$ & $\begin{array}{l}\text { No distinction } \\
\text { made }\end{array}$ & $\begin{array}{l}\text { Gastrointestinal symptoms } \\
\text { associated with lower rates } \\
\text { of death and ICU admission }\end{array}$ \\
\hline \multicolumn{7}{|c|}{ Studies on paediatric patients } \\
\hline Xu et al. ${ }^{79}$ & $\begin{array}{l}\text { Guangdong, } \\
\text { China }\end{array}$ & $\begin{array}{l}\text { Until } 20 \text { Feb } \\
2020\end{array}$ & 10 & Diarrhoea $30 \%$; vomiting 0 & On admission & NA \\
\hline Cai et al. ${ }^{81}$ & China & $\begin{array}{l}\text { Jan } 19 \text { to } \\
3 \text { Feb } 2020\end{array}$ & 10 & Diarrhoea 0\% & $\begin{array}{l}\text { During } \\
\text { hospitalization }\end{array}$ & NA \\
\hline Lu et al. ${ }^{170}$ & Wuhan, China & $\begin{array}{l}28 \text { Jan to } \\
26 \text { Feb } 2020\end{array}$ & 171 & Diarrhoea 8.8\%; vomiting 6.4\% & $\begin{array}{l}\text { No distinction } \\
\text { made }\end{array}$ & NA \\
\hline Fakiri et al. ${ }^{171}$ & $\begin{array}{l}\text { Marrakesh, } \\
\text { Morocco }\end{array}$ & $\begin{array}{l}2 \text { Mar to } \\
1 \text { Apr } 2020\end{array}$ & 74 & Diarrhoea 5.4\% & $\begin{array}{l}\text { No distinction } \\
\text { made }\end{array}$ & NA \\
\hline
\end{tabular}


Table 1 (cont.) | Studies reporting proportion of patients with COVID-19 with gastrointestinal symptoms

\begin{tabular}{|c|c|c|c|c|c|c|}
\hline Study & Region & Time & $\begin{array}{l}\text { Total } \\
\text { number of } \\
\text { patients }\end{array}$ & Gastrointestinal symptom & $\begin{array}{l}\text { Point at which } \\
\text { symptoms } \\
\text { were reported }\end{array}$ & $\begin{array}{l}\text { Gastrointestinal } \\
\text { symptoms and disease } \\
\text { severity }\end{array}$ \\
\hline \multicolumn{7}{|c|}{ Studies on paediatric patients (cont.) } \\
\hline $\begin{array}{l}\text { Mahmoudi } \\
\text { et al. }{ }^{173}\end{array}$ & Tehran, Iran & $\begin{array}{l}7 \text { Mar to } \\
30 \text { Mar } 2020\end{array}$ & 35 & $\begin{array}{l}\text { Diarrhoea } 26 \% \text {; vomiting } \\
29 \% \text {; abdominal pain } 11 \%\end{array}$ & $\begin{array}{l}\text { No distinction } \\
\text { made }\end{array}$ & NA \\
\hline Parri et al. ${ }^{175}$ & Italy & $\begin{array}{l}3 \text { Mar to } \\
27 \text { Mar } 2020\end{array}$ & 100 & $\begin{array}{l}\text { Diarrhoea } 9 \% \text {; nausea } \\
\text { or vomiting } 10 \%\end{array}$ & $\begin{array}{l}\text { No distinction } \\
\text { made }\end{array}$ & NA \\
\hline
\end{tabular}

TABLE 1 contains selected studies that take sample size, region, symptom collection time point (on admission or during hospitalization) and research methods (prospective or retrospective) into consideration. In detail, studies on adult patients that clarified whether the gastrointestinal symptoms were collected before or after admission and with a sample size $>100$ were included; the two studies that distinguish the symptoms on admission and during hospitalization are placed but samples $<100$ are placed at the top of the table. Two studies in Chile and California, with a sample size of $>100$ but missing the symptom collection time point, were included owing to the few studies in these regions. One New York study with a large sample size was also included. The number of paediatric studies containing gastrointestinal symptoms are limited; studies in different regions with symptom collection time point or a sample size $>35$ were included. CDC, Centers for

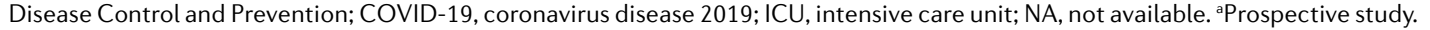

estimates of gastrointestinal symptoms were diarrhoea $(7.7 \%)$, nausea or vomiting $(7.8 \%)$, and abdominal pain $(2.7 \%)^{30}$. It is worth mentioning that different studies have adopted different criteria for what constitutes gastrointestinal symptoms. In some studies, gastrointestinal symptoms only included diarrhoea, nausea and vomiting $^{16,19,23}$, whereas in others, symptoms such as loss of taste, abdominal pain and loss of appetite were also included ${ }^{17,24,25,29}$. For example, a multicentre study in China reported gastrointestinal symptoms, including diarrhoea (3.8\%), nausea and vomiting (5\%), as less common symptoms ${ }^{11}$, whereas one single-centre study in Baltimore, USA, reported gastrointestinal symptoms, including nausea, vomiting, diarrhoea, abdominal pain, anorexia, haematochezia, and loss of smell or taste, in more than $70 \%$ of patients with COVID-19 (REF. ${ }^{24}$ ). The great variation in the proportion of patients with gastrointestinal symptoms among different studies might also be related to geographical region ${ }^{30}$ and whether symptoms were reported on admission or during hospitalization ${ }^{25}$. Moreover, patients might receive different medications for COVID-19, some of which are likely to induce diarrhoea as an adverse event, for example, lopinavir or antibiotics. In addition, given the differing epidemic prevention policies between regions, the lack of data on COVID-19 in some communities, and the fact that mild cases are less reported or are not admitted to hospital in some regions, there might be deviations in the proportion of gastrointestinal symptoms reported between studies.
As a consequence, there is also disagreement among studies examining possible correlations between gastrointestinal symptoms and disease severity. According to an early meta-analysis that included 3,022 patients from 9 studies, no statistically significant difference could be identified between patients with or without gastrointestinal symptoms (20.5\% versus $18.2 \%)^{31}$. Additionally, according to two studies in New York, patients with gastrointestinal symptoms had lower rates of death than those without gastrointestinal symptoms $(8.5 \%$ versus $16.5 \%$ and $0 \%$ versus $5 \%$, respectively) ${ }^{21,32}$. Consistent with that finding, a single-centre study in Italy reported that the presence of gastrointestinal symptoms was inversely associated with the risk of clinical deterioration ${ }^{19}$. By contrast, a later meta-analysis that included 4,243 patients from 60 studies globally revealed that the pooled prevalence of all gastrointestinal symptoms was higher in patients with severe disease than in patients with mild disease (17.1\% versus $11.8 \%)^{15}$. Moreover, a multicentre study in China found that more patients with diarrhoea showed severe symptoms of pneumonia than did patients without diarrhoea ( $53 \%$ versus $19 \%)^{28}$. Further prospective studies with consistent standards for describing gastrointestinal symptoms and that exclude adverse effects caused by medications are required to determine whether gastrointestinal symptoms have a bona fide correlation to disease severity.

Diarrhoea is the most common gastrointestinal symptom in COVID-19; 2-50\% of patients with COVID-19 have been reported to have diarrhoea ${ }^{11,16-29}$ (TABLE 1).
According to a study of 651 patients in Zhejiang, China, among 53 patients with diarrhoea, the duration of diarrhoea lasted 1-9 days and, in most cases, the diarrhoea was self-limiting ${ }^{23}$. The adverse events related to treatments provided during hospitalization can partially explain the diarrhoea symptoms reported by some patients with COVID-19. In one open-label, phase II trial, 127 adults with COVID-19 were administered lopinavir-ritonavir ${ }^{33}$; the adverse effects included self-limited nausea and diarrhoea in 52 (41\%) patients, which were mostly resolved within 3 days after drug initiation. Interestingly, a 22-year-old man with COVID-19 showed no respiratory symptoms but did present a 4-day history of diarrhoea and low-grade fever at the onset of illness ${ }^{34}$. Furthermore, according to a single-centre case series study ( $n=138$ ) in Wuhan, China, $10.1 \%$ of patients initially presented with diarrhoea and nausea 1-2 days prior to the development of fever and dyspnoea ${ }^{35}$. These studies suggest that gastrointestinal symptoms might be a symptom of onset in some patients with COVID-19.

Notably, patients with other respiratory virus-related diseases, including SARS, MERS $^{36}$ (TABLE 2) and even severe influenza, also present with gastrointestinal symptoms $^{37,38}$. For example, $20 \%$ of patients with SARS reported diarrhoea ${ }^{39}$. Furthermore, 97\% (65 of 67) of patients with SARS reportedly tested positive for SARS-CoV RNA in faeces ${ }^{40}$, and an autopsy study of 5 patients showed infection in a limited number of enterocytes and lymphocytes ${ }^{41}$. As many as one-third of patients with severe MERS reported 
Table 2 | Comparison of SARS-CoV-2, SARS-CoV and MERS-CoV infection

\begin{tabular}{|c|c|c|c|}
\hline Characteristics & SARS-CoV-2 (REFS $\left.{ }^{4,30,83}\right)$ & SARS-CoV 36,40 & MERS-CoV 36,43 \\
\hline \multicolumn{4}{|l|}{ Epidemiology } \\
\hline Confirmed cases & $105,658,476^{a}$ & 8,096 & 2,519 \\
\hline Mortality (\%) & $2.2^{\mathrm{a}}$ & 9.6 & 34.4 \\
\hline Incubation period (days) & $1-14$ & $2-14$ & $2-14$ \\
\hline \multicolumn{4}{|c|}{ Gastrointestinal characteristics } \\
\hline Nausea (\%) & 7.8 & $20-35$ & 21.0 \\
\hline Vomiting (\%) & 7.8 & $20-35$ & 21.0 \\
\hline Diarrhoea (\%) & 7.7 & $20-25$ & 26.0 \\
\hline $\begin{array}{l}\text { Percentage of patients with } \\
\text { positive faecal samples }\end{array}$ & 55.0 & 97.0 & $14.5^{\mathrm{b}}$ \\
\hline
\end{tabular}

gastrointestinal symptoms ${ }^{42}$ and, in one study, $14.6 \%$ tested positive for viral RNA in faecal samples ${ }^{43}$. According to several cohort studies, $40-70 \%$ of patients infected with $\mathrm{H} 5 \mathrm{~N} 1$ had gastrointestinal symptoms $\mathrm{s}^{38,44,45}$ and, in one case report, diarrhoea preceded respiratory manifestations by up to 1 week $^{46}$. Interestingly, influenza is actually an enteric virus in birds ${ }^{47,48}$ and other coronaviruses, such as mouse hepatitis virus and bovine coronavirus $^{49,50}$, also establish intestinal infection in animals.

The mechanism of diarrhoea in patients with COVID-19 is still largely unknown. Experimental studies from other viruses have indicated that several factors might lead to diarrhoea, including alterations in gut microbiota ${ }^{51,52}$, osmotic diarrhoea due to malabsorption or inflammation that is secondary to enterocyte damage ${ }^{53,54}$, release of virulent proteins or toxins ${ }^{53}$, and viral-induced intestinal fluid and electrolyte secretion by activation of the enteric nervous system ${ }^{55}$. Two retrospective studies of 87 patients with COVID-19 showed that patients with diarrhoea are more likely to test positive for viral RNA in stool ${ }^{15,18}$ and, in one study ( $\left.n=59\right)$, the faecal viral load was positively associated with diarrhoea $(P=0.06)^{15}$. This aspect is similar to what was observed during SARS-CoV infection ${ }^{56}$, indicating a potential correlation between intestinal infection and diarrhoea. Notably, the histological examination of both patients with SARS and patients with COVID-19 in several case studies showed that the mucosal epithelium of the duodenum and rectum had no major damage $^{39,57-60}$. Considering the limited number of cases, more histological analyses are needed to determine whether there is enterocyte damage in the intestine, which could lead to diarrhoea.
Immune mechanisms have been proposed to play an important role in viral diarrhoea such as in norovirus infections ${ }^{61}$. Indeed, inflammatory immune responses in patients with COVID-19 with diarrhoea have been reported. Calprotectin, which is an inflammatory marker secreted by infiltrated neutrophils, was detected in high concentrations in the faecal samples of 22 patients with COVID-19 with involvement of inflammation. Additionally, according to a mouse study, excessive levels of inflammatory factors caused by lung infection of influenza might also exacerbate diarrhoea symptoms through changes in composition of the gut microbiota, including decreased levels of segmented filamentous bacteria and Lactobacillus and/or Lactococcus as well as an increase in Enterobacteriaceae, independently of direct intestinal infection ${ }^{52}$. In several cases, patients with COVID-19 with gastrointestinal symptoms had no detectable viral RNA in stool ${ }^{15,63}$, which suggests that SARS-CoV-2 could also cause diarrhoea that is independent of intestinal infection.

Further studies are needed to investigate the specific mechanisms underlying the gastrointestinal symptoms caused by SARS-CoV-2 infection. For example, a comparison of the proportion of gastrointestinal symptoms among patients with or without detectable virus in the intestine would be useful to understand the contribution of direct intestinal infection on the occurrence of gastrointestinal symptoms. Given that ACE2 has been shown to function in gut microbial ecology $y^{64}$ and that alterations in the gut microbiota of patients with COVID-19 have been diarrhoea $^{62}$, highlighting the potential reported $^{65,66}$, investigations are warranted to determine whether these alterations in gut microbiota are related to intestinal peristalsis and diarrhoea.

\section{Evidence of intestinal infection Intestinal expression of SARS-CoV-2} receptor and serine protease. Cell entry of SARS-CoV-2 is dependent upon binding of its spike (S) proteins to the cellular surface protein ACE2; priming of $S$ proteins by host cell transmembrane serine protease 2 (TMPRSS2) is also essential ${ }^{67}$. Analyses of single-cell transcriptomics data in humans revealed that ACE2 and TMPRSS2 are co-expressed in lung alveolar type 2 cells, oesophageal upper epithelial and gland cells, and in absorptive enterocytes from the ileum and colon ${ }^{68}$. Notably, absorptive enterocytes in the small intestine were found to express the highest levels of ACE2 in the human body ${ }^{14}$. Meanwhile, a small fraction of human colon epithelial cells expressed ACE2 at moderate levels ${ }^{69}$.

According to immunohistochemistry studies of ACE2, an abundant expression of ACE2 can be observed in the brush border of the intestinal enterocytes in the ileum ${ }^{70,71}$. ACE2 is also present in the vascular endothelium and vascular smooth muscle cells in the submucosa of the ileum ${ }^{70}$. In the colon, ACE2 is mainly present in the blood vessels and muscular layers ${ }^{70}$, consistent with single-cell transcriptomics data showing that relatively few colon epithelial cells express ACE2 (REF. ${ }^{69}$ ). Taken together, the expression patterns of ACE2 and TMPRSS2 indicate the potential for SARS-CoV-2 intestinal infection (FIG. 1).

Detection and isolation of SARS-CoV-2 from faeces. Multiple studies have reported the positive detection of SARS-CoV-2 RNA in faecal samples or rectal swabs from patients with COVID-19 (REFS ${ }^{15,59,72-85}$ ) (TABLE 3). According to a retrospective cohort study in Zhejiang, China, viral RNA was detected in the stool of $59 \%$ (55 of 93) of patients ${ }^{86}$. The median duration of viral RNA in stool was 22 days $^{86}$. Viral loads from stool samples were found to peak later in the disease, generally 2-3 weeks after symptom onset ${ }^{86,87}$. The viral RNA load in stool samples apparently reflected the course in sputum in $86 \%$ (6 of 7) of cases in a study in Germany ${ }^{88}$. However, in some patients, faecal samples remained positive for virus even after the respiratory and/or sputum samples exhibited no detectable virus ${ }^{79,88}$. In some cases, the viral load in faeces reached $10^{7}$ copies/g $\left(\mathrm{REF}^{88}\right)$, even higher than that in pharyngeal swabs. The presence and persistence of such large amounts of viral RNA in faeces 
is unlikely to be explained by only the swallowing of virus particles replicated in the throat but rather suggests the potential for enteric infection of SARS-CoV-2.

The viral SARS-CoV-2 subgenomic mRNA (sgmRNA) is transcribed in actively replicating cells and SARS-CoV-2 sgmRNA has been detected in faecal samples of one patient, indicating the presence of actively infected cells in the gastrointestinal tract ${ }^{88}$. As sgmRNAs are not packaged into virions, it is therefore unlikely that they can pass through the gastrointestinal tract following their digestion by RNAse. Consistently, sgmRNAs last longer in faeces than in throat swabs, indicating that they are unlikely to be derived from the respiratory tract ${ }^{88}$. In addition, infectious virus particles have

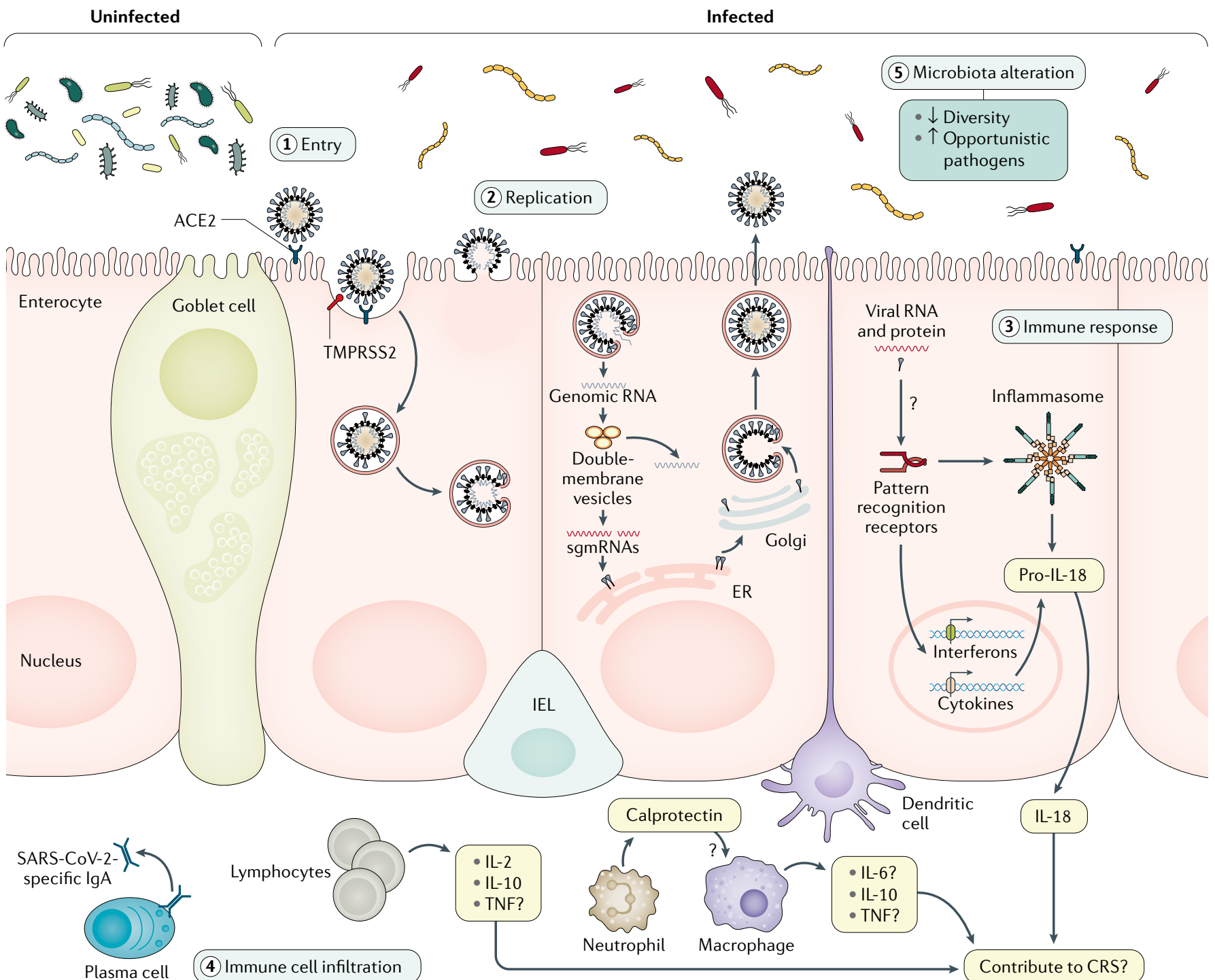

Fig. 1 | Evidence of SARS-CoV-2 intestinal infection. This figure shows the putative mechanisms for severe acute respiratory syndrome coronavirus 2 (SARS-CoV-2) intestinal infection. Angiotensin-converting enzyme 2 (ACE2) is mainly expressed on the brush border of enterocytes in the ileum and colon. Cell entry by SARS-CoV-2 (1) begins with the binding of spike (S) proteins to ACE2. Host cell transmembrane serine protease 2 (TMPRSS2) cleaves the $S$ protein. Subsequently, the cell membrane fuses with the viral membrane and SARS-CoV-2 genomic RNA is released into the cytoplasm. Based on human intestinal organoid studies, SARS-CoV-2 primarily infects enterocytes but not goblet cells. The double membrane structure produced by virus replication (2) can be observed in the infected cells and the virus protein can be detected in the endoplasmic reticulum (ER). Newly assembled viral particles were released predominantly from the apical side into the lumen. The detection of subgenomic mRNA (sgmRNA) can serve as evidence of active viral replication in the intestine. SARS-CoV-2 infection activates an interferon-mediated immune response (3) in human organoids. Levels of the intestinal epithelial cell-specific inflammatory factor IL-18, which is activated by inflammasomes, have been shown to increase in patients with severe coronavirus disease 2019 (COVID-19). However, how SARS-CoV-2 triggers immune response in the gut in humans is not yet well understood, including the role of inflammatory factors caused by intestinal infection and their contribution to cytokine release syndrome (CRS), and requires further investigation. The histological examination of human intestinal samples revealed that lymphocytes and inflammatory cells infiltrated the lamina propria (4). Patients with diarrhoea exhibited increased faecal calprotectin levels, released mainly by infiltrated neutrophils. However, whether intestinal infiltrations of T cells, B cells, macrophages and neutrophils as well as of their secreted cytokine and IgA are correlated with disease severity is still unknown. SARS-CoV-2 infection altered the gut microbiota community structure (5). The enrichment of opportunistic pathogens and the depletion of beneficial commensals was observed in patients with COVID-19. These changes were correlated with the expression of inflammatory factors in the serum of these patients. However, whether the microbiota profile can predict the occurrence of CRS and whether modulation of the microbiota can resolve CRS need further study. IEL, intraepithelial lymphocyte. 
Table 3 | Summary of patients with SARS-CoV-2-positive faecal or rectal swabs

\begin{tabular}{|c|c|c|c|c|c|}
\hline Author & Region & $\begin{array}{l}\text { Number of } \\
\text { patients } \\
\text { with positive } \\
\text { stool/rectal } \\
\text { swab sample }\end{array}$ & $\begin{array}{l}\text { Duration } \\
\text { of positive } \\
\text { infection } \\
\text { (days) }\end{array}$ & $\begin{array}{l}\text { Patients with } \\
\text { positive stool/ } \\
\text { rectal sample } \\
\text { after negative } \\
\text { respiratory } \\
\text { system samples }\end{array}$ & $\begin{array}{l}\text { Duration } \\
\text { after positive } \\
\text { respiratory } \\
\text { system } \\
\text { samples } \\
\text { (days) }\end{array}$ \\
\hline \multicolumn{6}{|l|}{ Adult patients } \\
\hline Lin et al. ${ }^{72}$ & $\begin{array}{l}\text { Guangzhou, } \\
\text { China }\end{array}$ & $46 / 217$ (21.2\%) & $3-18$ & $30 / 46(65.2 \%)$ & $3-15$ \\
\hline Ling et al. ${ }^{73}$ & $\begin{array}{l}\text { Shanghai, } \\
\text { China }\end{array}$ & $54 / 66(81.8 \%)$ & $9-16^{a}$ & $43 / 55$ (78.2\%) & $1-4$ \\
\hline Cheung et al. ${ }^{15}$ & $\begin{array}{l}\text { Hong Kong, } \\
\text { China }\end{array}$ & 9/59 (15.3\%) & $\begin{array}{l}\text { Data } \\
\text { collection on } \\
\text { presentation }\end{array}$ & NA & NA \\
\hline $\begin{array}{l}\text { Kujawski } \\
\text { et al. }{ }^{74}\end{array}$ & USA & $7 / 12$ (58.3\%) & $1-12$ & $1 / 7(14.3 \%)$ & 1 \\
\hline Lo et al..$^{75}$ & Macau, China & $9 / 9(100 \%)$ & $1-18$ & $1 / 9(11.1 \%)$ & 6 \\
\hline Young et al. ${ }^{76}$ & Singapore & $4 / 8(50 \%)$ & $1-7$ & $1 / 4(25 \%)$ & 5 \\
\hline \multicolumn{6}{|c|}{ Paediatric patients } \\
\hline Hua et al..$^{77}$ & $\begin{array}{l}\text { Zhejiang, } \\
\text { China }\end{array}$ & $32 / 35$ (91.4\%) & NA & $\begin{array}{l}18 / 35(51.4 \%) \text { on } \\
\text { discharge }\end{array}$ & $\begin{array}{l}>70 \text { days in } \\
\text { one child } \\
\text { since illness } \\
\text { onset }\end{array}$ \\
\hline Han et al..$^{78}$ & Seoul, Korea & $11 / 12$ (91.6\%) & $\begin{array}{l}80 \% \text { positive } \\
>3 \text { weeks }\end{array}$ & NA & NA \\
\hline Xu et al..$^{79}$ & $\begin{array}{l}\text { Guangzhou, } \\
\text { China }\end{array}$ & $8 / 10$ (80\%) & $3-28^{a}$ & $8 / 8(100 \%)$ & $3-30^{a}$ \\
\hline Liu et al. ${ }^{80}$ & $\begin{array}{l}\text { Shanghai, } \\
\text { China }\end{array}$ & $8 / 9$ (89\%) & $28-66$ & $8 / 8(100 \%)$ & $14-52$ \\
\hline Cai et al. ${ }^{81}$ & China & $5 / 6(83.3 \%)$ & $18-30^{\mathrm{a}}$ & $5 / 5(100 \%)$ & $11-18$ \\
\hline Xing et al. ${ }^{82}$ & $\begin{array}{l}\text { Qingdao, } \\
\text { China }\end{array}$ & $3 / 3(100 \%)$ & $6-30$ & $3 / 3(100 \%)$ & $8-20$ \\
\hline \multicolumn{6}{|c|}{ No distinction made } \\
\hline Wu et al. ${ }^{83}$ & Zhuhai, China & $41 / 74$ (55.4\%) & $1-39$ & $32 / 41$ (78\%) & $1-33$ \\
\hline Xiao et al. ${ }^{59}$ & $\begin{array}{l}\text { Guangzhou, } \\
\text { China }\end{array}$ & $39 / 73(53.4 \%)$ & $1-12^{\mathrm{a}}$ & $17 / 39(43.6 \%)$ & NA \\
\hline Chen et al..$^{84}$ & Wuhan, China & $28 / 42$ (66.7\%) & $1-21^{a}$ & $18 / 28(64.3 \%)$ & $6-10$ \\
\hline Kim et al. ${ }^{85}$ & Korea & $8 / 15(53.3 \%)$ & $1-7$ & $2 / 8(25 \%)$ & $3-9$ \\
\hline
\end{tabular}

This is a table with selected studies; studies that were published before 1 Aug 2020, sample size $\geq 3$, and proportion and duration of positive virus in the stool of the patients with COVID-19 were selected. NA, not

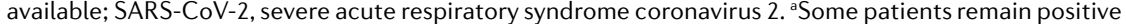
at last follow-up.

been successfully isolated from patients' faeces $^{89-92}$. The combination of very high concentrations of viral RNA, the detection of sgmRNA and the prolonged detectability in faecal samples compared with respiratory samples strongly suggests that SARS-CoV-2 actively replicates in the gastrointestinal tract (FIG. 1).

\section{Endoscopic and histological examination in} COVID-19. Endoscopy and biopsy samples of the oesophagus, stomach, duodenum and colon were taken from a 78-year-old patient with COVID-19 in Guangdong Province, China, who showed symptoms of upper gastrointestinal bleeding ${ }^{59}$.
Staining for nucleocapsid proteins of SARS-CoV-2 revealed their presence in the gastrointestinal epithelium but not in the oesophageal epithelium in this patient. However, no substantial damage to the mucosal epithelium of the oesophagus, stomach, duodenum or rectum was observed. Numerous infiltrating plasma cells and lymphocytes with interstitial oedema were found in the lamina propria of the stomach, duodenum and rectum of this patient, which indicated an inflammatory response in the digestive system caused by SARS-CoV-2 infection (FIG. 1).

A similar phenomenon was also found in one patient with rectal adenocarcinoma who developed fever and cough on day 3 postoperatively and was diagnosed with COVID-19 on day 7 (REF. ${ }^{60}$ ). SARS-CoV-2 RNA was detected in surgical rectal tissues and virions were observed under electron microscopy of the surgical tissues on day 0 . These results implied that the virus might have survived and replicated in the intestine even before respiratory symptoms appeared. SARS-CoV-2 antigens were detected in intestinal epithelial cells as well as in lymphocytes and macrophages of the lamina propria $^{60}$, similar to what has been described for SARS-CoV ${ }^{41}$.

Furthermore, a study that included pathological analysis of colonoscopy samples from one patient with COVID-19 confirmed SARS-CoV-2 infection in the colon by in situ hybridization for viral RNA and by electron microscopy ${ }^{93}$. Importantly, substantial damage to the colon mucosa marked by injury to the luminal epithelial cells and goblet cell depletion was detected in colonoscopy samples ${ }^{93}$, which was not observed in two previous studies ${ }^{59,60}$. Taken together, although more histological analyses might be needed to determine whether there is enterocyte damage in the intestine, the endoscopic and histological examination in patients with COVID-19 provides direct evidence of active SARS-CoV-2 replication in the intestine.

\section{Increased intestinal levels of pro-inflammatory cytokines and} calprotectin. CRS is considered a leading cause of severe pneumonia and even death during SARS-CoV-2 infection ${ }^{9}$. Following an early increase in type 1 (antiviral, interferons) and type 3 (antibacterial or antifungal, IL-17 and IL-22) immune responses, patients with moderate COVID-19 $(n=80)$ displayed a progressive reduction in plasma cytokine levels ${ }^{94}$. However, patients with severe disease $(n=33)$ maintained these elevated responses for approximately 20 days after the onset of symptoms ${ }^{94}$. Higher plasma levels of both pro-inflammatory and anti-inflammatory cytokines IL-2, IL-6, IL-7, IL-10, GM-CSF, IP10, CCL2 (also known as MCP1), MIP1a and TNF have been detected in patients with severe disease compared with those with moderate disease ${ }^{94,95}$. Moreover, histological examination of autopsy samples from a patient with severe COVID-19 showed bilateral diffuse alveolar damage and mononuclear inflammatory lymphocytes in both lungs ${ }^{96}$. Together, these studies indicated that CRS probably plays a major role in causing acute respiratory distress syndrome and death ${ }^{94-96}$. 
Increasing evidence of enteric infections with SARS-CoV-2 highlights the possible influence of intestinal inflammation on gastrointestinal symptoms and even on lung symptoms associated with COVID-19. Faecal calprotectin, which is largely expressed by neutrophil granulocytes, has been widely adopted as a reliable faecal biomarker of intestinal inflammation ${ }^{97}$. In a study including 40 Australian patients, patients with COVID-19 with diarrhoea $(n=22)$, and especially 9 patients with ongoing diarrhoea, had elevated faecal calprotectin concentrations compared with patients with COVID-19 without diarrhoea $(n=18)^{62}$. Moreover, faecal calprotectin production was significantly positively correlated with serum IL-6 concentration $(P<0.001)^{62}$. The intestine produces high levels of IL-6 (REFS ${ }^{98-100}$ ), indicating a potential contribution of intestinal calprotectin and/or IL-6 in the increased serum IL-6 concentrations observed in patients with severe COVID-19 (REF. ${ }^{94}$ ). Intriguingly, tocilizumab, a recombinant humanized anti-human IL-6 receptor monoclonal antibody, immediately improved the clinical outcomes of 21 patients with severe and critical COVID-19 in a single arm trial ${ }^{101,102}$. However, in a randomized, double-blind, placebo-controlled phase III trial of 243 patients, tocilizumab was not effective in preventing intubation or death in moderately ill hospitalized patients with COVID-19 within 28 days ( 17 of 161 (10.6\%) versus 10 of $80(12.5 \%) ; P=0.64)$, although there were fewer severe cases in the tocilizumab-treated group than in the placebo-treated group (13 of $161(8.1 \%)$ versus 14 of $81(17.3 \%) ; P=0.03)^{103}$. In another phase III trial of 389 hospitalized patients with COVID-19 pneumonia who were not receiving mechanical ventilation, tocilizumab reduced the composite outcome of mechanical ventilation or death $(12 \%$ versus $19.3 \% ; P=0.04$ ) by day 28 (REF. ${ }^{104}$ ). However, when death from any cause alone was evaluated as a secondary outcome, no statistically significant difference was observed between the tocilizumab group and the placebo control group (10.4\% versus $8.6 \%)^{104}$. Moreover, a randomized clinical trial of 131 patients with moderate-to-severe COVID-19 comparing the effect of tocilizumab versus standard of care (antibiotics, antiviral agents, corticosteroids, vasopressor support and anticoagulants) showed that tocilizumab might reduce the need for mechanical and non-invasive ventilation or death by day 14 (17\% versus $27 \%$ ) but not mortality by day $28\left(\right.$ REF. $\left.^{105}\right)$.
Further studies are necessary to confirm these observations, especially testing the effects of tocilizumab on patients with COVID-19 at different stages across the disease course and with different severities of the disease.

Interestingly, the level of another inflammatory cytokine mainly expressed in intestinal epithelial cells, IL-18 (REFS ${ }^{106-108}$ ), was found to increase upon fever onset and remain highly elevated in the acute phase of SARS-CoV infection in 88 patients ${ }^{109}$. Similarly, three studies respectively found that IL-18 levels were markedly increased in the serum ${ }^{94,110}$ or faeces ${ }^{65}$ of patients with COVID-19 and that increased levels of IL- 18 were positively correlated with severe disease $\mathrm{e}^{94}$. IL-18 maturation is induced by the activation of the intestinal inflammasome ${ }^{106,108,111}$. IL-18 participates in several inflammatory diseases (for example, inflammatory bowel disease, metabolic syndrome and type 2 diabetes mellitus) and lung diseases (for example, allergic asthma, chronic obstructive pulmonary disease and acute lung injury) $)^{112-114}$. Based on experimental and clinical evidence, neutralizing IL- 18 by anti-IL- 18 antibody or its natural inhibitor, soluble IL-18 binding protein (IL-18BP), can attenuate the inflammatory conditions ${ }^{112,115,116}$. Interestingly, IL-18 is elevated in patients with COVID-19 but not in patients with seasonal influenza ${ }^{65}$. Additionally, the IL-18 levels were higher in the faecal supernatants obtained from patients with COVID-19 who tested positive for SARS-CoV-2 RNA than in those faecal samples that tested negative, suggesting that IL-18 can potentially serve as an indicator for intestinal infection in COVID-19 $\left(\mathrm{REF}^{65}\right)$. We postulate that intestinal release of IL-18 during SARS-CoV-2 enteric infection might also be involved in CRS in COVID-19. Further investigations into the correlation between IL-18 expression and disease severity could facilitate the potential application of IL-18 blockade in patients with severe COVID-19 with intestinal infection (FIG. 1).

Alterations in the gut microbiota in
COVID-19. Previous studies have shown
that respiratory viral infections are
associated with altered gut microbiota
composition ${ }^{52,117,118}$. Several groups have
investigated changes in the faecal microbiota
of patients with SARS-CoV-2 infection
during hospitalization ${ }^{66,119}$. Consistently,
an enrichment of opportunistic pathogens
(such as Clostridium hathewayi, Actinomyces
viscosus, Bacteroides nordii and Streptococcus
spp.) concurrent with the depletion

of beneficial commensals (including members of the Ruminococcaceae and Lachnospiraceae families) was observed in 15 patients with COVID-19 compared with healthy controls in a pilot study ${ }^{119}$. Specifically, in one patient, gut dysbiosis persisted for as long as 17 days after discharge ${ }^{119}$. The genus Coprobacillus, which contains species that strongly upregulate colonic expression of ACE2 in mice ${ }^{120}$, were the top bacteria positively associated with COVID-19 severity ${ }^{119}$. In addition, four Bacteroides species, which were associated with downregulation of ACE2 expression in the murine colon ${ }^{120}$, showed a statistically significant inverse correlation with faecal SARS-CoV-2 load $^{119}$. Moreover, another study compared alterations in gut microbiota among 62 patients with COVID-19, patients with seasonal influenza and healthy individuals as controls ${ }^{65}$. An analysis of alpha diversity showed a statistically significant decrease in mean species diversity (chaol index) in patients with SARS-CoV-2 compared with both patients with influenza and healthy controls. Moreover, patients with COVID19 had a relatively higher abundance of Streptococcus, Clostridium, Lactobacillus, and Bifidobacterium and lower levels of Bacteroidetes, Roseburia, Faecalibacterium, Coprococcus and Parabacteroides compared with healthy individuals as controls, with IL-18 expression strongly correlating with several bacteria genera such as Peptostreptococcus, Fusobacterium and Citrobacter $^{65}$. These observations bring a potential connection between microbiota dysbiosis and infection and/or inflammation caused by SARS-CoV-2 in the intestine. It is worth noting that the patients with COVID-19 involved in those studies were under medical care; further studies on treatment-naive patients would be of benefit to better characterize the connection between SARS-CoV-2 infection and gut microbiota.

Given that SARS-CoV-2 infection has been shown to lead to specific alterations in the gut microbiota, further study of the relationship between shifts in gut microbial communities and cytokine release will help to determine whether these changes directly or indirectly affect serum cytokine levels in patients. In addition, as gut microbiota-derived metabolites play important roles in the maintenance of intestinal homeostasis ${ }^{121-123}$, and given that several metabolites, such as acetate and butyrate, reportedly protect against respiratory virus infection in mice studies $^{124,125}$, analyses of gut metabolism 
Table 4 | Current evidence on SARS-CoV-2 replication in vitro and in vivo

\begin{tabular}{|c|c|}
\hline Model & Phenotypes during SARS-CoV-2 infection \\
\hline \multicolumn{2}{|l|}{ In vitro studies } \\
\hline $\begin{array}{l}\text { SARS-CoV-2-infected human } \\
\text { intestinal-derived cell line }{ }^{69,126}\end{array}$ & $\begin{array}{l}\text { Efficiently infected Caco-2 cells; partial infection } \\
\text { T84 cells }\end{array}$ \\
\hline Bat organoids ${ }^{92}$ & Susceptible to SARS-CoV-2 infection \\
\hline Human small intestine organoids ${ }^{127,128}$ & Susceptible to SARS-CoV-2 infection; induction of ISGs \\
\hline Human colon-derived organoids ${ }^{69,92,93}$ & $\begin{array}{l}\text { Infection of } 10 \% \text { of colon organoid cells; induction } \\
\text { of type III interferons and ISGs }\end{array}$ \\
\hline \multicolumn{2}{|l|}{ Animal model ${ }^{a}$} \\
\hline hACE2 transgenic mice ${ }^{138}$ & $\begin{array}{l}\text { Viral RNA in the intestine on day } 1 \text { post-infection; } \\
\text { no histological changes in gastrointestinal tract }\end{array}$ \\
\hline hACE2 knock-in mice ${ }^{133}$ & $\begin{array}{l}\text { Viral RNA in faeces of aged mice; intragastric infection } \\
\text { led to lung inflammation }\end{array}$ \\
\hline Golden Syrian hamster ${ }^{137,142}$ & $\begin{array}{l}\text { Continuous viral RNA shedding in faeces; viral antigens } \\
\text { in the intestine; successfully infected via fomites }\end{array}$ \\
\hline Ferret ${ }^{134,139,141}$ & $\begin{array}{l}\text { Continuous viral RNA shedding in faeces; viral antigens } \\
\text { in the intestine; isolation of infectious particles } \\
\text { from nasal swabs after intragastric transfer of faecal } \\
\text { supernatant }\end{array}$ \\
\hline Cat $^{139}$ & Positive rectal swabs; viral RNA in the intestine \\
\hline $\operatorname{Dog}^{139}$ & Positive rectal swabs \\
\hline Rhesus macaques ${ }^{135,136}$ & $\begin{array}{l}\text { Prolonged faecal viral shedding after being negative in } \\
\text { respiratory samples; viral RNA in the intestinal tissue; } \\
\text { inflammatory infiltration in the intestine; viral antigens } \\
\text { in the intestine }\end{array}$ \\
\hline Cynomolgus macaques ${ }^{144}$ & Viral RNA in faeces; viral RNA in ileum \\
\hline
\end{tabular}

hACE2, human angiotensin-converting enzyme 2; ISGs, interferon-stimulated genes; SARS-CoV-2, severe acute respiratory syndrome coronavirus $2 .{ }^{a}$ Animals were infected via intranasal route unless otherwise noted.

in patients with COVID-19 would also be informative of whether alterations in microbiota can cause aberrant immune responses.

\section{Intestinal infection models} In vitro models for SARS-CoV-2 intestinal infection. Several studies based on human cell lines and organoids have confirmed that SARS-CoV-2 can infect intestinal cells in vitro ${ }^{69,92,126-128}$ (TABLE 4). SARS-CoV-2 was reported to infect cells of the colon carcinoma-derived lines T84 and Caco-2 (REFS ${ }^{69,126}$ ), both of which were found to express ACE2 and TMPRSS2, as confirmed by quantitative $\mathrm{PCR}^{69}$. Interestingly, much higher amounts of infectious viral particles were produced in Caco- 2 cells than in the human lung adenocarcinoma cell line Calu-3 (the virus titres were about $10^{4}$ median tissue culture infectious dose (TCID50)/ml produced by Calu- 3 cells versus $10^{8} \mathrm{TCID} 50 / \mathrm{ml}$ produced by Caco- 2 cells when infected with SARS-CoV-2 at a multiplicity of infection of 3$)^{69}$.

Intestinal organoids can also be used as a convenient model to study intestinal viral infections such as rotaviral infection ${ }^{106,129}$. Indeed, SARS-CoV-2 can readily infect human small intestine organoids $s^{127,128}$. Infection of proliferative enterocyte progenitors or ApoA $1^{+}$enterocytes, but not goblet cells, has been reported. Mature viral particles were released from the basolateral and apical cells of the lumen ${ }^{128}$. Transcriptomic or quantitative PCR analysis of SARS-CoV-2-infected intestinal organoids revealed a strong induction of interferon-stimulated genes, although the ability of SARS-CoV-2 to induce a type I and/or type III interferon response varies among different studies ${ }^{92,127,128}$. SARS-CoV-2 was also reported to infect human colon-derived organoids ${ }^{69,92,93}$. Quantification revealed that $\sim 10 \%$ of cells were infected in colon organoids, consistent with the low percentage of colon epithelial cells found to express ACE2 in single-cell transcriptomics data ${ }^{69}$. The infection of colon organoids did not lead to type I interferon (IFN $\beta 1$ ) production ${ }^{69,92}$ but did result in a strong upregulation of type III interferon (IFN $\lambda)^{69}$. Interestingly, both human lung organoids and colonic organoids were cultured in one study ${ }^{93}$ and, although only lung organoids were used to screen drug candidates that are capable of inhibiting SARS-CoV-2 entry, colonic organoids were used for drug efficacy testing and showed similar results as lung organoids, suggesting that intestinal organoids can also serve as a highly relevant infection model to test viable candidate therapeutics ${ }^{93}$.

As SARS-CoV-2 showed 96\% identity to the bat coronavirus BatCoV RaTG13 (REF. ${ }^{3}$ ) and the intestine of Chinese horseshoe bat is considered the reservoir of many related coronaviruses $^{130,131}$, bat intestinal organoids have been cultured to explore SARS-CoV-2 replication in the bat gut ${ }^{92}$. Indeed, bat organoids were fully susceptible to human SARS-CoV-2 infection and sustained robust viral replication ${ }^{92}$. These findings indicated that bat intestinal organoids could therefore also be used for mechanistic studies of SARS-CoV-2 intestinal infection. Taken together, these in vitro studies strongly suggest that SARS-CoV-2 can enter and replicate in intestinal epithelial cells.

\section{Evidence of intestinal SARS-CoV-2 infection in animal models. SARS-CoV-2 cannot} infect wild-type mice ${ }^{132}$ as the entry of SARS-CoV-2 relies on the binding of human ACE2 (hACE2) but not of mouse ACE2. Thus, many efforts have been made to establish suitable animal models for mimicking specific aspects of SARS-CoV-2 infection in humans ${ }^{133-139}$ (TABLE 4).

Mice expressing hACE2 have been widely used for SARS-CoV-2 infection ${ }^{133,138,140}$; the adenovirus-mediated expression of hACE2 in the lung of the mice, for example, can serve as a useful model for COVID-19 pathogenesis, vaccination and treatment ${ }^{140}$. However, as hACE2 is transiently expressed in the lung via intranasal adenovirus inoculation, virtually no viral RNA was detected in the intestines of AdV-hACE2-transduced mice ${ }^{140}$.

The targeted infection of the intestine by hACE2-expressed adenovirus might be needed to test intestinal infection of SARS-CoV-2. Transgenic mice that express hACE2 have also been explored to mimic mild SARS-CoV-2 infection ${ }^{138}$. However, upon intranasal inoculation of SARS-CoV-2 in hACE2 transgenic mice, viral RNA was only transiently detected at the first day post-infection and no histopathological lesions of SARS-CoV-2 were observed. The failure to establish intestinal infection in this model could be related to suboptimal virus replication in transgenic mice, as less than $10^{4}$ TCID50 per ml virus was detected in the lung and, moreover, pathological changes in lung tissue were minimal ${ }^{138}$.

For more physiological exploration of the infection process, knock-in mice 
expressing hACE2 under the control of the mouse ACE2 promoter can serve as a more appropriate infection model than transgenic lines. The peak viral RNA titre in the lungs of hACE2 knock-in mice reached up to $10^{8}$ copies/g (REF. ${ }^{133}$ ). Interestingly, intranasal inoculation of aged mice (30 weeks old) with $4 \times 10^{5}$ plaque-forming units of SARS-CoV-2 resulted in the detection of high levels of viral RNA in faeces $\left(2.9 \times 10^{5} \text { copies } / g\right)^{133}$. However, as many factors could result in the intestinal detection of viral RNA, such as swallowing of the virus, virus replication in the intestine and the fact that mice, being coprophagic, could be 'inoculating' themselves with faecal matter, the source of the viral RNA in faeces warrants further investigation. Notably, intragastric SARS-CoV-2 infection in hACE2 knock-in mice led to interstitial inflammation with alveolar septal thickening as well as the accumulation of detectable levels of viral RNA and antigens in lung tissue $^{133}$, suggesting that intragastric administration of SARS-CoV-2 could also establish productive infection and lead to pulmonary pathological changes in hACE2 mice. This result also highlights the possibility of faecal-oral transmission of SARS-CoV-2. Notably, viral RNA was not detectable in either intestinal samples or serum via intranasal or intragastric infection in this mouse model ${ }^{133}$, which is probably due to sample collection at late time points of infection (5-6 days post infection (dpi)), when the weight loss of mice was already recovered $^{133}$. Further measurements on whether there is an increase of faecal virus shedding and intestinal histopathology are needed to further prove the establishment of intestinal infections.

In addition to mouse models, evidence from several other animal models also supports intestinal viral infection.

SARS-CoV-2 has been reported to infect ferrets $^{134,139,141}$. Viral RNA was detected in some of the rectal swabs of virus-inoculated ferrets $^{134,139,141}$, some of which continued to test positive for 4-8 days (blood (for $4 \mathrm{dpi}$ ), nasal washes (for $8 \mathrm{dpi}$ ), urine (for $8 \mathrm{dpi}$ ) and in faeces (for $8 \mathrm{dpi}$ )). Similarly, viral antigens were detectable in the intestines of these animals ${ }^{134}$. Moreover, when naive ferrets were inoculated with faecal supernatants of infected specimens, infectious virions could be isolated from subsequent nasal washes, thereby providing direct evidence of the faecal-oral transmission of SARS-CoV-2 in ferrets ${ }^{134}$.

Furthermore, the intranasal infection of golden Syrian hamsters with SARS-CoV-2 showed intestinal infection: viral RNA was continuously detectable in the faecal samples of infected hamsters for 14 days and viral antigen was detected in intestinal epithelial cells ${ }^{137,142}$. Severe intestinal epithelial cell necrosis, damaged and deformed intestinal villi, and increased lamina propria mononuclear cell infiltration were observed ${ }^{142}$, thereby providing direct evidence for intestinal infection of SARS-CoV-2 in hamsters. Interestingly, naive golden Syrian hamsters could be infected via fomites ${ }^{127}$, objects or substances capable of carrying infectious organisms. However, it is unclear whether infection via fomites was possible via the faecal-oral route as the isolation of infectious virus particles in faecal samples failed, probably owing to the toxicity of the faecal extracts on the Vero cells used for the detection of infectious virus ${ }^{134,143}$. Further in vivo experiments by intragastric inoculation of faecal supernatants into naive animals might be needed to verify the feasibility of faecal-oral transmission.

SARS-CoV-2 has been shown to infect non-human primates, such as Rhesus macaques ${ }^{135,136}$ and cynomolgus macaques ${ }^{144}$, providing the most genetically relevant infection model to mimic human infection. Upon intranasal inoculation of SARS-CoV-2 to seven Rhesus macaques at $10^{6}$ TCID50, viral RNA-positive anal swabs were observed at $3 \mathrm{dpi}$ in all infected monkeys, followed by a continuous decline of the positive numbers of anal swabs until viral RNA was undetectable at $14 \mathrm{dpi}$ (REF. ${ }^{136}$ ). Virus-positive cells and inflammatory cell infiltration were both observed in the jejunum and colon of these animals. In another study, viral RNA-positive anal swabs were reported in two of eight Rhesus macaques infected with SARS-CoV-2 via a combination of intranasal $(0.5 \mathrm{ml}$ per nostril), intratracheal $(4 \mathrm{ml})$, oral $(1 \mathrm{ml})$ and ocular $(0.25 \mathrm{ml}$ per eye) inoculation of a $4 \times 10^{5} \mathrm{TCID} 50 / \mathrm{ml}$ virus dilution ${ }^{135}$. At $3 \mathrm{dpi}$, small numbers of antigen-positive lymphocytes and macrophages in the lamina propria of the intestinal tract of all four macaques were detected. Viral mRNA, which indicates active viral replication, was detected in the respiratory tract and lymphoid tissues of all four Rhesus macaques and detected in the stomach tissue of one of four Rhesus macaques at $3 \mathrm{dpi}\left(\mathrm{REF}^{135}\right)$. Similar to clinical studies in patients, prolonged shedding of viral RNA in rectal swabs was observed even after nose and throat swabs returned negative from one of four Rhesus macaques that were monitored until 21 dpi (REF. ${ }^{135}$ ). In another study, Rhesus macaques were infected with an intragastric $(n=5)$ or intranasal $(n=5)$ challenge with $1 \mathrm{ml}$ of $1 \times 10^{7}$ plaque-forming units of SARS-CoV-2 $\left(\right.$ REF. $\left.^{145}\right)$. Notably, both intranasal and intragastric inoculation caused the infiltration of inflammatory cells and loss of mucosal epithelium in gastrointestinal tissues. The immunohistochemistry staining of cleaved caspase 3 was observed in the stomach, jejunum, colon and rectum at $1 \mathrm{dpi}$ in both the intranasal and intragastric groups $^{145}$, highlighting the apoptosis caused by SARS-CoV-2 infection in gastrointestinal epithelial cells. A decreased number of mucin-containing goblet cells, the hallmark of ulcerative colitis ${ }^{146}$, was observed in the small intestine at $4 \mathrm{dpi}$ in the intranasal group and as early as $1 \mathrm{dpi}$ in the intragastric group ${ }^{145}$. Consistently, a decrease in goblet cell numbers has also been reported in patients with COVID-19 (REF. ${ }^{93}$ ), indicating the induced intestinal inflammation by SARS-CoV-2. The expression of CD68, a marker for macrophages, substantially increased in the intestine at the earlier stage (at 1, 4 and $7 \mathrm{dpi}$ ) of infection by either intranasal or intragastric challenge, which is consistent with the expression of inflammatory cytokines produced by macrophages such as IL-1, IL-6, IL-12 and TNF ${ }^{145}$. Interestingly, in this study, intragastric inoculation with SARS-CoV-2 led to pneumonia; however, the viral RNAs in the lung were unable to be detected ${ }^{145}$. These results led to a hypothesis that activated macrophages in the gastrointestinal tract might induce tissue damage in the digestive tract, and even in the lung, by secreting inflammatory cytokines.

In addition, viral RNA was also found in the anal swabs of SARS-CoV-2-infected cats and $\operatorname{dog} s^{139}$. Taken together, results from a variety of animal models (mice, ferrets, hamsters and non-human primates) strongly support intestinal infection of SARS-CoV-2 and the potential for faecal-oral transmission.

\section{Potential faecal-oral transmission}

Respiratory droplets and close contact have been shown to be the main routes of SARS-CoV-2 transmission ${ }^{147,148}$. However, in one study including 96 patients in China, $59 \%$ of patients shed viral RNA in stool ${ }^{86}$, which raised concerns of a possible faecaloral transmission route for SARS-CoV-2 in humans (FIG. 2). In 2003, a large community outbreak of SARS, affecting more than 300 residents in Amoy Gardens in Hong Kong, was presumed to be related to faecal-oral transmission ${ }^{149}$. A patient with SARS with diarrhoea visited one building in Amoy Gardens and used the toilet; subsequently, 
321 cases of SARS were located in clusters within this building. The floor drain traps, which are designed as a barrier between the floor and the drain, had dried out at the time of the outbreak; however, swabs taken from the affected apartments and the sewer manholes found no genetic material of SARS ${ }^{149}$. Thus, direct evidence of faecal-oral transmission is missing in that outbreak. According to a report, based on circumstantial evidence, faecal-aerosol transmission might have caused the community outbreak of COVID-19 in a high-rise building in Guangzhou, China ${ }^{150}$. Nine patients infected with SARS-CoV-2 in three families lived in vertically aligned flats connected by drainage pipes in the master bathrooms. The first family infected had a travel history to the COVID-19 outbreak epicentre of Wuhan in January 2020, whilst the other two families had no travel history and showed a later onset of symptoms in February 2020. No evidence was found for transmission via the elevator or elsewhere. Both the confirmed time points of infections and the locations of positive environmental samples are consistent with the vertical spread of virus-laden aerosols via stacks and vents ${ }^{150}$.
Three key issues should be discussed to determine whether SARS-CoV-2 can establish faecal-oral transmission. First, whether SARS-CoV-2 can tolerate exposure to gastric acid to subsequently establish an intestinal infection. Second, it remains unknown whether infectious virus particles can tolerate intestinal fluid and can then be shed through faeces. Finally, whether the virus particles in fomites are of sufficient concentration and infectivity for the subsequent transmission needs to be determined.

\section{Can SARS-CoV-2 tolerate gastric acid} and survive passage into the gut? Enteric viruses, such as rotaviruses and noroviruses, which are characterized by an absence of a lipid envelope, are well known to be transmitted by the faecal-oral route ${ }^{151}$, whereas enveloped respiratory viruses, such as influenza virus, are thought to be cleared by the digestive juice and mucus layer in the gastrointestinal tract. SARS-CoV-2 has been found to rapidly lose infectivity in simulated gastric fluid in vitro ${ }^{127}$. As evidence of intestinal infection of SARS-CoV-2 is well reported, several protection mechanisms previously reported in influenza viruses and other respiratory coronavirus are proposed to help SARS-CoV-2 retain its infectivity in the intestine ${ }^{152}$. Hirose et al. showed that, although influenza virions are vulnerable to simulated digestive juices (that is, gastric acid and bile or pancreatic juice) in vitro, highly viscous mucus, such as viscous sputum and nasal mucus, protects the virions, thereby allowing the virus to retain its infectivity ${ }^{152}$. Moreover, both SARS-CoV and SARS-CoV-2 were reported to have infected a small number of lymphocytes ${ }^{41,60}$ and viral RNA was detected in the blood of patients infected with SARS-CoV-2 $\left(\right.$ REF. $\left.^{90}\right)$. Whether SARS-CoV-2 could spread from the lungs to the gut carried by immune cells warrants further investigation. Notably, these protective mechanisms are typically used to explain how SARS-CoV-2 might spread from the respiratory system to the intestine in already-infected patients. However, the viral ability to establish an intestinal infection does not equate to its ability to transmit via a faecal-oral route.

The stomach environment varies over the course of gastric residence of a meal, which might affect the tolerance of respiratory viruses in gastric fluid ${ }^{153}$. Based on human clinical studies, the fed-state gastric fluid

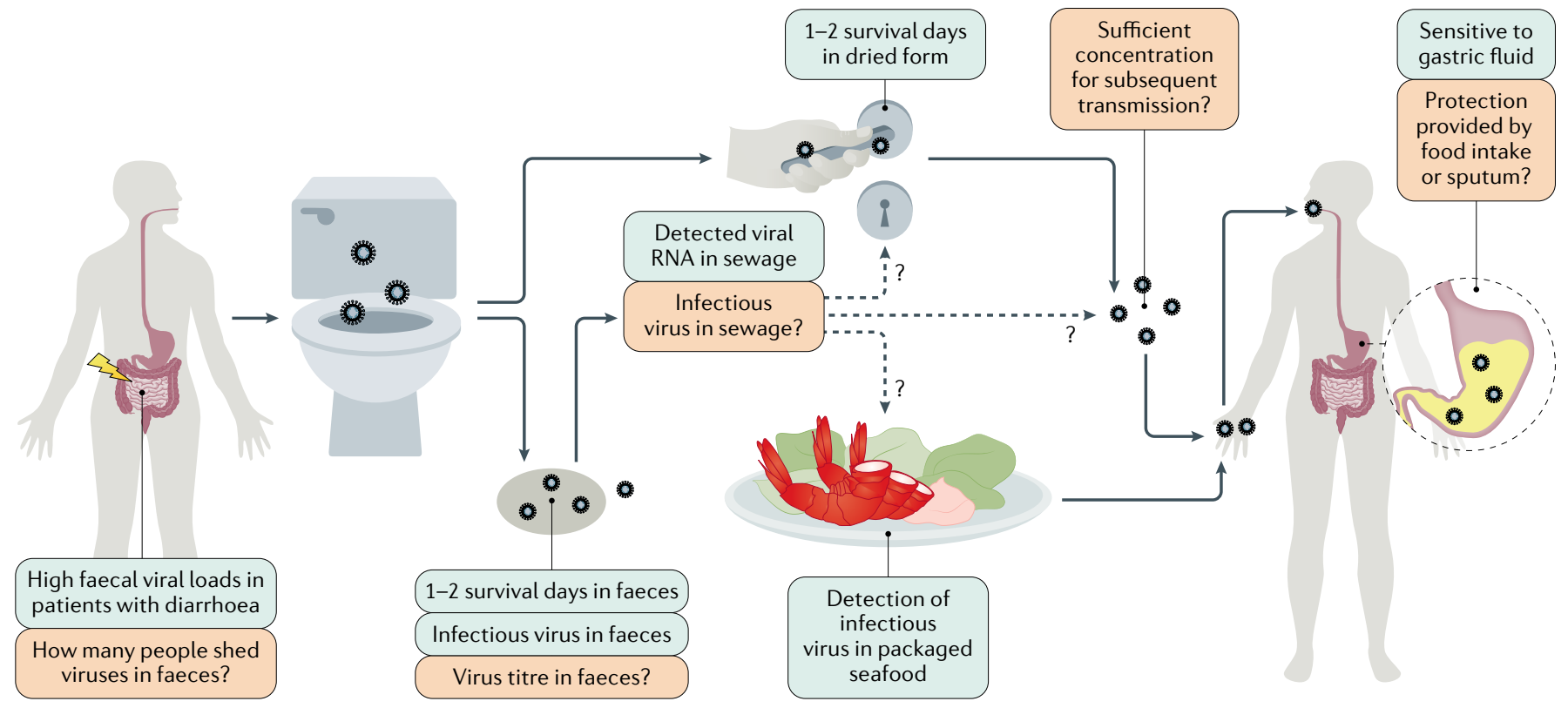

Fig. 2 | The potential faecal-oral transmission of SARS-CoV-2. The exact faecal-oral transmission route is not yet established for severe acute respiratory syndrome coronavirus 2 (SARS-CoV-2); green boxes show confirmed findings, whereas orange boxes depict open questions. High viral loads were found in the faecal samples of patients with coronavirus disease 2019 (COVID-19) and diarrhoea. However, the number of patients with COVID-19 that shed infectious viruses (but not viral RNA) in faeces remains unknown. In several cases, infectious virus was isolated in faeces and an in vitro study reported $1-2$ survival days of SARS-CoV-2 in faeces. Thus, the virus might possibly contaminate sewage, water, and food supplies and possibly contaminate bathroom sites via faecal-aerosol transmission.
Consistent with this hypothesis, viral RNA was detected in sewage and on toilet seats, flush buttons and door handles. Moreover, the detection of infectious virus in packaged seafood was reported in China. However, the research on virus titre in faecal fomites is still lacking. Whether the virus titres in faecal fomites are of sufficient concentration and infectivity for subsequent transmission remains unknown. Moreover, SARS-CoV-2 can tolerate human small intestinal fluid but rapidly loses infectivity in gastric fluid within 10 minutes. It remains unclear whether the virus can survive during food intake or whether it is protected by sputum, which is a previously reported by-pass mechanism of Middle East respiratory syndrome coronavirus and influenza. 
has a hyperosmolar content and higher $\mathrm{pH}$ compared with fasting-state gastric fluid ${ }^{153}$. In vitro, the fasting-state-simulated gastric fluid is often a salt solution that contains sodium taurocholate, lecithin and pepsin at a $\mathrm{pH}$ of 1.6, whereas the fed-state-simulated gastric fluid is a milk-based medium to simulate the carbohydrate to protein to fat ratio observed in the stomach after the administration of meals and has a $\mathrm{pH}$ of 5 (REF. ${ }^{154}$ ). Coronavirus MERS-CoV and $\mathrm{HCoV}-229 \mathrm{E}$ (an alphacoronavirus that causes mild respiratory infection in humans) were found to rapidly lose most of their infectivity in fasting-state-simulated gastric fluid $^{143}$. However, by contrast, the infectivity of MERS-CoV and HCoV-229E were unaffected after $2 \mathrm{~h}$ of exposure to fed-state-simulated gastric fluid ${ }^{143}$. As the research on SARS-CoV-2 infectivity is based on fasting-state-simulated gastric fluid, study of the SARS-CoV-2 infection process in fed-state-simulated gastric fluid is essential to determine whether food and eating can influence the survival of SARS-CoV-2 through passage into the gut.

Can infectious SARS-CoV-2 be shed in faeces? Shedding through faeces is another essential characteristic of faecaloral transmission. A study in human duodenum enteroids found that the virus was released predominantly from the apical side into the lumen, suggesting the possibility of viral shedding and accumulation in the faeces of patients with COVID-19 (REF. ${ }^{127}$ ). Previous studies have shown that different coronaviruses have different tolerances to small intestinal fluid. Nearly half of MERS-CoV particles were found to remain viable after $2 \mathrm{~h}$ of exposure to fed-state-simulated intestinal fluid, whereas $\mathrm{HCoV}-229 \mathrm{E}$ was shown to be rapidly inactivated in the same conditions ${ }^{143}$. According to another report, residual SARS-CoV-2 virus can be found in fasting-state intestinal fluid after $24 \mathrm{~h}$ of incubation ${ }^{127}$. By contrast, only $20 \%$ of SARS-CoV-2 virions remained infective after $1 \mathrm{~h}$ of incubation in simulated human colonic fluids in the fasting state ${ }^{127}$. A clear understanding of the capacity for SARS-CoV-2 survival in fed-state colon fluid is still lacking. However, based on current research, SARS-CoV-2 could plausibly remain infectious in the stool, especially when the patient has diarrhoea symptoms ${ }^{127}$. Consistent with these findings, several reports have shown successful isolation of SARS-CoV-2 from faeces in humans ${ }^{89-91}$. For example, intact virus was isolated from the stool specimen of one patient with laboratory-confirmed COVID-19 severe pneumonia in Heilongjiang, China ${ }^{89}$, and from one patient in Guangzhou, China, who later died ${ }^{91}$. The failure of other studies to isolate infectious SARS-CoV-2 from stool might be owing to the mild disease courses of these cases, mild gastrointestinal symptoms, low virus titre or the toxicity of intestine homogenates towards the cultured cells ${ }^{88,143}$.

\section{Can SARS-CoV-2 maintain concentration and infectivity in faecal fomites? Several} studies have investigated the infectivity of SARS-CoV-2 under various environmental conditions. One study reported that SARS-CoV-2 was able to retain viability for 3-5 days in dried glass surfaces and for 7 days in solution at room temperature ${ }^{155}$. Moreover, SARS-CoV-2 RNA was detected in sewage in Australia, USA and France ${ }^{156-159}$, and the maximum concentrations of viral RNA reach to $10^{6}$ copies per litre $\left(\mathrm{REF}^{156}\right)$. Although studies on isolating infectious virus in sewage are lacking, the ability to maintain infectivity in liquids makes it possible that SARS-CoV-2 can be transmitted through sewage. In addition, SARS-CoV-2 can survive longer at low temperatures $\left(14 \text { days at } 4^{\circ} \mathrm{C}\right)^{155}$; therefore, the detection of SARS-CoV-2 viral RNA and infectious virus in packaged seafood has highlighted the risk of faecal-oral transmission ${ }^{160}$.

Moreover, an in vitro study that added infectious virus $\left(10^{6.5} \mathrm{TCID} 50 / \mathrm{ml}\right)$ to watery stool derived from human samples reported that SARS-CoV-2 retained viability but showed a 5-log reduction in infectivity in stool at room temperature for 1-2 days ${ }^{155}$. However, as the viral titre of SARS-CoV-2 in the faeces of patients with COVID-19 and those asymptomatic but confirmed as SARS-CoV-2 positive have not been well studied, future research is needed to examine the infectious virus titre in faeces, the viability of SARS-CoV-2 in sewage and the minimum infectious viral dose in animal models to explore whether SARS-CoV-2 can be transmitted via the faecal-oral route.

\section{Conclusions}

Current research provides strong evidence for the intestinal infection of SARS-CoV-2 (TABLE 5). Further research is still needed to determine the mechanism of intestinal infection, the correlation with CRS and the possibility of faecal-oral transmission (TABLE 5). Many studies have reported the detection of viral RNA in the stool and gastrointestinal tracts of patients with COVID-19. As some patients with COVID-19 were reported to have prolonged, persistent viral RNA in rectal swabs or faeces $^{82,83}$, further studies are needed to accurately quantify the proportion of patients that positively shed viral RNA in faeces and have active viral replication in the intestine. It also remains unknown for how long active intestinal infection by SARS-CoV-2 can persist. Furthermore, comparing the proportion of gastrointestinal symptoms among patients with or without intestinal infection by measuring viral genomic RNA and subgenomic viral RNA transcripts shed in the faeces can be informative on the contribution of direct intestinal infection to these gastrointestinal symptoms.

According to endoscopic and histological examination of patients with COVID-19, intestinal infection with SARS-CoV-2 caused inflammatory infiltration ${ }^{59,60}$. SARS-CoV-2 infection also altered the composition of the gut microbiota, which correlated with the elevated expression of inflammatory cytokines such as IL-2, IL-4, IL-6, IL-10 and IL-18 (REFS ${ }^{65,66,161}$ ). Furthermore, faecal calprotectin was found to accumulate in high levels in the stools of patients with COVID-19 with diarrhoea, which was also correlated with serum levels of the inflammatory cytokine IL-6 $\left(R_{E F}{ }^{62}\right)$. It is therefore worth further scrutiny to determine whether higher intestinal inflammatory infiltration or more severe dysbiosis of microbiota are correlated with higher cytokine serum levels, the occurrence of CRS and/or disease severity in patients with COVID-19. In addition, further studies in animal models can help illustrate the relative contributions of intestinal inflammation and gut microbiota to CRS and disease severity.

$\operatorname{Ig} \mathrm{A}$ is mainly produced in mucosal surfaces. Humans produce more IgA (40-60 mg/kg per day) than all other immunoglobulin isotypes combined and at least $80 \%$ of all plasma cells are located in the intestinal lamina propria ${ }^{162,163}$. A study found that $33 \%$ (2 of 6 ) of patients with COVID-19 showed an IgA-dominant serum immunoglobin pattern ${ }^{164}$. According to a study including 159 patients with COVID-19, SARS-CoV-2-specific IgA is likely to be detected earlier than IgG and IgA contributed to virus neutralization to a greater extent than $\operatorname{IgG}^{165}$. Other work showed that IgA detection exhibited the highest positive diagnostic rate compared with $\operatorname{IgM}$ and $\operatorname{IgG}$ detection at 4-10 days after symptom onset ${ }^{166}$. Consistently, in a case report, one patient with IgA 
Table 5 | Current evidence and outlook on the intestinal infection and potential faecal-oral transmission of SARS-CoV-2

\begin{tabular}{|c|c|c|}
\hline Category & Current evidence & Further questions \\
\hline \multicolumn{3}{|c|}{ Intestinal infection by SARS-CoV-2 } \\
\hline \multirow[t]{10}{*}{ Clinical evidence } & $\begin{array}{l}\text { Nearly half of patients with COVID-19 are positive for } \\
\text { SARS-CoV-2 RNA detection in faecal samples }{ }^{15}\end{array}$ & $\begin{array}{l}\text { How many patients with positive faecal tests have active viral } \\
\text { replication as measured by viral subgenomic mRNA? }\end{array}$ \\
\hline & \multirow[t]{2}{*}{$\begin{array}{l}\text { Persistence of viral RNA in faecal compared with respiratory } \\
\text { samples for as long as a month after discharge } \mathrm{e}^{77,80,83}\end{array}$} & $\begin{array}{l}\text { Can intestinal infection serve as a reservoir for re-infection } \\
\text { in the lung? }\end{array}$ \\
\hline & & $\begin{array}{l}\text { Does intestinal infection of SARS-CoV-2 enhance its } \\
\text { mutation rate? }\end{array}$ \\
\hline & \multirow{2}{*}{$\begin{array}{l}\text { Approximately } 5-70 \% \text { of patients with COVID-19 reported } \\
\text { gastrointestinal symptoms }{ }^{11,24}\end{array}$} & $\begin{array}{l}\text { Clear distinctions should be established between } \\
\text { gastrointestinal symptoms presented on admission and } \\
\text { the gastrointestinal symptoms caused by medications }\end{array}$ \\
\hline & & $\begin{array}{l}\text { A correlation is not yet established between gastrointestinal } \\
\text { symptoms, the presence of faecal SARS-CoV-2 RNA and/or } \\
\text { active viral replication }\end{array}$ \\
\hline & \multirow{2}{*}{$\begin{array}{l}\text { SARS-CoV-2 infection altered gut microbiota, correlated } \\
\text { with elevated expression of inflammatory cytokines such } \\
\text { as IL-2 and IL-18 (REFS }\end{array}$} & $\begin{array}{l}\text { Does intestinal infection lead to increased expression of } \\
\text { inflammatory cytokines in the intestines and/or serum? }\end{array}$ \\
\hline & & \multirow{2}{*}{$\begin{array}{l}\text { If so, do intestinal infection and elevated cytokine levels } \\
\text { contribute to cytokine release syndrome or correlate with } \\
\text { disease severity? }\end{array}$} \\
\hline & $\begin{array}{l}\text { High levels of faecal calprotectin in patients with COVID-19 } \\
\text { with diarrhoea, which were positively correlated with IL-6 } \\
\text { levels in serum } 62\end{array}$ & \\
\hline & \multirow{2}{*}{$\begin{array}{l}\text { IgA dominated in the early stage of SARS-CoV-2-specific } \\
\text { humoral responses and was more potent in neutralization } \\
\text { than } \lg G^{165}\end{array}$} & $\begin{array}{l}\text { Does intestinal mucosa contribute to lgA production during } \\
\text { SARS-CoV-2 infection? }\end{array}$ \\
\hline & & $\begin{array}{l}\text { Will oral administration of SARS-CoV-2 vaccines achieve } \\
\text { better efficacy? }\end{array}$ \\
\hline In vitro evidence & $\begin{array}{l}\text { SARS-CoV- } 2 \text { infects intestinal cell lines and human } \\
\text { intestinal organoids, thereby mediating the production } \\
\text { of ISGs }{ }^{69,92,93,127,128}\end{array}$ & $\begin{array}{l}\text { Can human intestinal organoids serve as a highly relevant } \\
\text { infection model to characterize the complete SARS-CoV-2 } \\
\text { life cycle and test viable candidate therapeutics? }\end{array}$ \\
\hline \multirow{2}{*}{$\begin{array}{l}\text { Clinical/ } \\
\text { environmental } \\
\text { evidence }\end{array}$} & \multirow{2}{*}{$\begin{array}{l}\text { Infectious virions were isolated from faecal samples } \\
\text { of patients with COVID-19 (REFS }\end{array}$} & $\begin{array}{l}\text { How long can SARS-CoV-2 survive in sewage or food } \\
\text { surfaces? }\end{array}$ \\
\hline & & $\begin{array}{l}\text { Can SARS-CoV-2 maintain sufficient concentration and } \\
\text { infectivity in fomites for subsequent transmission? }\end{array}$ \\
\hline \multirow[t]{4}{*}{ In vivo evidence } & Hamsters can be infected through SARS-CoV-2 fomites ${ }^{137}$ & \multirow{3}{*}{$\begin{array}{l}\text { Exploration of the exact route and timelines for faecal-oral } \\
\text { infection in animal models; systematic characterization of } \\
\text { the host response for lung infection and intestinal infection } \\
\text { in animal models }\end{array}$} \\
\hline & $\begin{array}{l}\text { ACE2 knock-in mice can be infected by intragastric } \\
\left.\text { SARS-CoV-2 (REF. }{ }^{133}\right)\end{array}$ & \\
\hline & $\begin{array}{l}\text { Naive ferrets can be infected by intragastric faecal } \\
\text { supernatant from infected ferrets }{ }^{134}\end{array}$ & \\
\hline & $\begin{array}{l}\text { Prolonged shedding of viral RNA in rectal swabs was observed } \\
\text { from one infected Rhesus macaque even after nose and throat } \\
\text { swabs returned negative }\end{array}$ & $\begin{array}{l}\text { More evidence in humans on whether SARS-CoV- } 2 \text { can infect } \\
\text { the next host via the faecal-oral route is needed }\end{array}$ \\
\hline
\end{tabular}

ACE2, angiotensin-converting enzyme 2; COVID-19, coronavirus disease 2019; hACE2, human ACE2; ISGs, interferon-stimulated genes; SARS-CoV-2, severe acute respiratory syndrome coronavirus 2 .

nephropathy showed an IgA-dominant pattern during SARS-CoV-2 infection and had reduced renal function during and after recovery from SARS-CoV-2 infection owing to the production of high levels of IgA in both serum and faeces ${ }^{167}$. Together, these reports suggest that IgA is the main type of immunoglobin induced by mucosal infection of SARS-CoV-2 and that IgA-mediated mucosal immunity plays a vital role in anti-SARS-CoV-2 infection. Notably, oral vaccination has also been discussed to prevent subsequent respiratory diseases by activating gut mucosal immunity ${ }^{168,169}$. Thus, whether oral administration of SARS-CoV-2 vaccines might achieve better efficacy and longer protection would be interesting to test.
In vivo animal studies have shown that gavage with faecal supernatant or exposure to faecal fomites can infect a proportion of animals ${ }^{134,137}$. Thus, more evidence is clearly required to unequivocally demonstrate that SARS-CoV-2 can establish a faecaloral transmission route. First, it remains unknown what proportion of people who are infected shed infectious virus particles 
in faeces. Second, the virus titre in faeces and the minimum infectious dose of SARS-CoV-2 are both still unresolved. A rigorous and systematic determination of whether the virus titre in faecal fomites can exceed the minimum infection dose is essential to accurately quantify the true risk of SARS-CoV-2 transmission through a faecal-oral route.

Meng Guo iD 1,2,7, Wanyin Tao ${ }^{1,2,7}$ Richard A. Flavell (iD ${ }^{3,4 凶}$ and Shu Zhu (D) 1,2,5,6凶

${ }^{\prime}$ Department of Digestive Disease, The First Affiliated Hospital of USTC, Division of Life Sciences and Medicine, University of Science and Technology of China, Hefei, China.

${ }^{2}$ Hefei National Laboratory for Physical Sciences at Microscale, the CAS Key Laboratory of Innate Immunity and Chronic Disease, School of Basic Medical Sciences, Division of Life Sciences and Medicine, University of Science and Technology of China, Hefei, China.

${ }^{3}$ Department of Immunobiology, Yale University School of Medicine, New Haven, CT, USA.

${ }^{4}$ Howard Hughes Medical Institute, Chevy Chase, MD, USA.

${ }^{5}$ School of Data Science, University of Science and Technology of China, Hefei, China.

${ }^{6}$ CAS Centre for Excellence in Cell and Molecular Biology, University of Science and Technology of China, Hefei, China.

${ }^{7}$ These authors contributed equally: Meng Guo, Wanyin Tao.

凶e-mail: richard.flavell@yale.edu; zhushu@ustc.edu.cn https://doi.org/10.1038/s41575-021-00416-6

\section{Published online 15 February 2021}

1. Fehr, A. R. \& Perlman, S. Coronaviruses: an overview of their replication and pathogenesis. Methods Mol. Biol. 1282, 1-23 (2015).

2. Cui, J., Li, F. \& Shi, Z. Origin and evolution of pathogenic coronaviruses. Nat. Rev. Microbiol. 17, 181-192 (2019).

3. Zhou, P. et al. A pneumonia outbreak associated with a new coronavirus of probable bat origin. Nature $\mathbf{5 7 9}$ 270-273 (2020)

4. WHO. WHO coronavirus disease (COVID-19) dashboard. WHO https://covid 19.who.int/ (2020).

5. Lan, J. et al. Structure of the SARS-CoV-2 spike receptor-binding domain bound to the ACE2 receptor. Nature 581, 215-220 (2020)

6. Blanco-Melo, D. et al. Imbalanced host response to SARS-CoV-2 drives development of COVID-19. Cell 181, 1036-1045.e9 (2020).

7. Channappanavar, R. et al. Dysregulated type I interferon and inflammatory monocyte-macrophage responses cause lethal pneumonia in SARS-CoV-infected mice. Cell Host Microbe 19, 181-193 (2016).

8. Kindler, E. et al. Efficient replication of the novel human betacoronavirus EMC on primary human epithelium highlights its zoonotic potential. $\mathrm{mBio} 4$, e00611-12 (2013).

9. Mehta, P. et al. COVID-19: consider cytokine storm syndromes and immunosuppression. Lancet 395 1033-1034 (2020)

10. Wu, Z. \& McGoogan, J. M. Characteristics of and important lessons from the coronavirus disease 2019 (COVID-19) outbreak in China: summary of a report of 72314 cases from the Chinese Center for Disease Control and Prevention. JAMA 323, 1239-1242 (2020).

11. Guan, W. J. et al. Clinical characteristics of coronavirus disease 2019 in China. N. Engl. J. Med. 382 1708-1720 (2020).

12. Chen, N. et al. Epidemiological and clinical characteristics of 99 cases of 2019 novel coronavirus pneumonia in Wuhan, China: a descriptive study. Lancet 395, 507-513 (2020).
13. Liang, W. et al. Diarrhoea may be underestimated: a missing link in 2019 novel coronavirus. Gut 69 $1141-1143$ (2020)

14. Qi, F., Qian, S., Zhang, S. \& Zhang, Z. Single cell RNA sequencing of 13 human tissues identify cell types and receptors of human coronaviruses. Biochem. Biophys. Res. Commun. 526, 135-140 (2020).

15. Cheung, K. S. et al. Gastrointestinal manifestations of SARS-CoV- 2 infection and virus load in fecal samples from a Hong Kong Cohort: systematic review and meta-analysis. Gastroenterology 159, 81-95 (2020).

16. Zhou, F. et al. Clinical course and risk factors for mortality of adult inpatients with COVID-19 in Wuhan, China: a retrospective cohort study. Lancet 395, 1054-1062 (2020).

17. Ferm, S. et al. Analysis of gastrointestinal and hepatic manifestations of SARS-CoV-2 infection in 892 patients in Queens, NY. Clin. Gastroenterol. Hepatol. 18, 2378-2379.e1 (2020).

18. Díaz, L. A. et al. Symptom profiles and risk factors for hospitalization in patients with SARS-CoV-2 and COVID-19: a large cohort from South America. Gastroenterology 159, 1148-1150 (2020).

19. Aghemo, A. et al. COVID-19 digestive system involvement and clinical outcomes in a large academic hospital in Milan, Italy. Clin. Gastroenterol. Hepatol. 18, 2366-2368.e3 (2020).

20. Remes-Troche, J. M. et al. Initial gastrointestinal manifestations in patients with SARS-CoV-2 in 112 patients from Veracruz (Southeastern Mexico). Gastroenterology 159, 1179-1181 (2020).

21. Hajifathalian, K. et al. Gastrointestinal and hepatic manifestations of 2019 novel coronavirus disease in a large cohort of infected patients from New York clinical implications. Gastroenterology 159 1137-1140.e2 (2020).

22. Redd, W. D. et al. Prevalence and characteristics of gastrointestinal symptoms in patients with severe acute respiratory syndrome coronavirus 2 infection in the United States: a multicenter cohort study. Gastroenterology 159, 765-767.e2 (2020).

23. Jin, X. et al. Epidemiological, clinical and virological characteristics of 74 cases of coronavirus-infected disease 2019 (COVID-19) with gastrointestinal symptoms. Gut 69, 1002-1009 (2020).

24. Chen, A. et al. Are gastrointestinal symptoms specific for COVID-19 infection? A prospective case-control study from the United States. Gastroenterology 159, 1161-1163.e2 (2020).

25. Lin, L. et al. Gastrointestinal symptoms of 95 cases with SARS-CoV-2 infection. Gut 69, 997-1001 (2020).

26. Sun, Y. et al. Epidemiological and clinical predictors of COVID-19. Clin. Infect. Dis. 71, 786-792 (2020).

27. Papa, A. et al. Gastrointestinal symptoms and digestive comorbidities in an Italian cohort of patients with COVID-19. Eur. Rev. Med. Pharmacol. Sci. 24 7506-7511 (2020)

28. Wan, Y. et al. Enteric involvement in hospitalised patients with COVID-19 outside Wuhan. Lancet Gastroenterol. Hepatol. 5, 534-535 (2020).

29. Cholankeril, G. et al. High prevalence of concurrent gastrointestinal manifestations in patients with severe acute respiratory syndrome coronavirus 2 : early experience from California. Gastroenterology 159, 775-777 (2020).

30. Sultan, S et al. AGA institute rapid review of the gastrointestinal and liver manifestations of COVID-19, meta-analysis of international data, and recommendations for the consultative management of patients with COVID-19. Gastroenterology 159, 320-334 e27 (2020)

31. Liu, J., Cui, M., Yang, T. \& Yao, P. Correlation between gastrointestinal symptoms and disease severity in patients with COVID-19: a systematic review and meta-analysis. BMJ Open Gastroenterol. 7, e000437 (2020).

32. Nobel, Y. R. et al. Gastrointestinal symptoms and coronavirus disease 2019: a case-control study from the United States. Gastroenterology 159 373-375.e2 (2020).

33. Hung I. F et al. Triple combination of interferon beta- $1 \mathrm{~b}$, lopinavir-ritonavir, and ribavirin in the treatment of patients admitted to hospital with COVID-19: an open-label, randomised, phase 2 trial. Lancet 395, 1695-1704 (2020).

34. Song, Y. et al. SARS-CoV-2 induced diarrhoea as onset symptom in patient with COVID-19. Gut 69 , 1143-1144 (2020)

35. Wang, D. et al. Clinical characteristics of 138 hospitalized patients with 2019 nove coronavirus-infected pneumonia in Wuhan, China. JAMA 323, 1061-1069 (2020).

36. Zumla, A., Hui, D. S. \& Perlman, S. Middle East respiratory syndrome. Lancet 386, 995-1007 (2015)

37. Wootton, S. H. et al. Detection of NH1N1 influenza virus in nonrespiratory sites among children. Pediatric Infect. Dis. J. 33, 95-96 (2014).

38. Yuen, K. Y. et al. Clinical features and rapid viral diagnosis of human disease associated with avian influenza A H5N 1 virus. Lancet 351, 467-471 (1998).

39. Leung, W. K. et al. Enteric involvement of severe acute respiratory syndrome-associated coronavirus infection. Gastroenterology 125, 1011-1017 (2003).

40. Peiris, J. S. et al. Clinical progression and viral load in a community outbreak of coronavirus-associated SARS pneumonia: a prospective study. Lancet 361 1767-1772 (2003).

41. Shi, X. et al. Severe acute respiratory syndrome associated coronavirus is detected in intestinal tissues of fatal cases. Am. J. Gastroenterol. 100, 169-176 (2005).

42. Arabi, Y. M. et al. Middle East respiratory syndrome. N. Engl. J. Med. 376, 584-594 (2017).

43. Corman, V. M. et al. Viral shedding and antibody response in 37 patients with Middle East respiratory syndrome coronavirus infection. Clin. Infect. Dis. 62 , 477-483 (2016).

44. Chotpitayasunondh, T. et al. Human disease from influenza A (H5N1), Thailand, 2004. Emerg. Infect. Dis. 11, 201-209 (2005)

45. Hien, T. T. et al. Avian influenza A (H5N1) in 10 patients in Vietnam. N. Engl. J. Med. 350, 1179-1188 (2004).

46. Beigel, J. H. et al. Avian influenza A (H5N1) infection in humans. N. Engl. J. Med. 353, 1374-1385 (2005).

47. Humberd, J., Guan, Y. \& Webster, R. G. Comparison of the replication of influenza A viruses in Chinese ring-necked pheasants and chukar partridges. J. Virol. 80, 2151-2161 (2006).

48. Alexander, D. J. An overview of the epidemiology of avian influenza. Vaccine 25, 5637-5644 (2007)

49. Körner, R. W., Majjouti, M., Alcazar, M. A. A. \& Mahabir, E. Of mice and men: the coronavirus MHV and mouse models as a translational approach to understand SARS-CoV-2. Viruses 12, 880 (2020).

50. Saif, L. J. \& Jung, K. Comparative pathogenesis of bovine and porcine respiratory coronaviruse in the animal host species and SARS-CoV-2 in humans. J. Clin. Microbiol. 58, e01355-20 (2020).

51. DuPont, H. L. Acute infectious diarrhea in immunocompetent adults. N. Engl. J. Med. 370 , 1532-1540 (2014).

52. Wang, J. et al. Respiratory influenza virus infection induces intestinal immune injury via microbiotamediated Th17 cell-dependent inflammation. J. Exp. Med. 211, 2397-2410 (2014).

53. Crawford, S. E. et al. Rotavirus infection. Nat. Rev Dis. Prim. 3, 17083 (2017).

54. Glass, R. I., Parashar, U. D. \& Estes, M. K. Norovirus gastroenteritis. N. Engl. J. Med. 361, 1776-1785 (2009).

55. Lundgren, $\mathrm{O}$. et al. Role of the enteric nervous system in the fluid and electrolyte secretion of rotavirus diarrhea. Science 287, 491-495 (2000).

56. Hung, I. F. et al. Viral loads in clinical specimens and SARS manifestations. Emerg. Infect. Dis. 10, 1550-1557 (2004).

57. To, K. F. et al. Tissue and cellular tropism of the coronavirus associated with severe acute respiratory syndrome: an in-situ hybridization study of fatal cases. J. Pathol. 202, 157-163 (2004)

58. Lang, Z.-W. et al. A clinicopathological study of three cases of severe acute respiratory syndrome (SARS). Pathology 35, 526-531 (2003).

59. Xiao, F. et al. Evidence for gastrointestinal infection of SARS-CoV-2. Gastroenterology 158, 1831-1833.e3 (2020).

60. Qian, Q. et al. Direct evidence of active SARS-CoV-2 replication in the intestine. Clin. Infect. Dis. https:// doi.org/10.1093/cid/ciaa925 (2020).

61. Hassan, E. \& Baldridge, M. T. Norovirus encounters in the gut: multifaceted interactions and disease outcomes. Mucosal Immunol. 12, 1259-1267 (2019).

62. Effenberger, M. et al. Faecal calprotectin indicates intestinal inflammation in COVID-19. Gut 69 1543-1544 (2020).

63. Park, S. K. et al. Detection of SARS-CoV-2 in fecal samples from patients with asymptomatic and mild COVID-19 in Korea. Clin. Gastroenterol. Hepatol. https://doi.org/10.1016/j.cgh.2020.06.005 (2020). 
64. Hashimoto, T. et al. ACE2 links amino acid malnutrition to microbial ecology and intestinal inflammation. Nature 487, 477-481 (2012)

65. Tao, W. et al. Analysis of the intestinal microbiota in COVID-19 patients and its correlation with the inflammatory factor IL-18. Med. Microecol. 5, 100023 (2020).

66. $\mathrm{Gu}, \mathrm{S}$. et al. Alterations of the gut microbiota in patients with coronavirus disease 2019 or $\mathrm{H} 1 \mathrm{~N} 1$ influenza. Clin. Infect. Dis. https://doi.org/10.1093/ $\mathrm{cid} / \mathrm{ciaa} 709$ (2020).

67. Hoffmann, M. et al. SARS-CoV-2 cell entry depends on ACE2 and TMPRSS2 and is blocked by a clinically proven protease inhibitor. Cell 181, 271-280.e8 (2020).

68. Zhang, $\mathrm{H}$. et al. Digestive system is a potential route of COVID-19: an analysis of single-cell coexpression pattern of key proteins in viral entry process. Gut 69 , 1010-1018 (2020)

69. Stanifer, M. L. et al. Critical role of type III interferon in controlling SARS-CoV-2 infection in human intestinal epithelial cells. Cell Rep. 32, 107863 (2020).

70. Hamming, I. et al. Tissue distribution of ACE2 protein, the functional receptor for SARS coronavirus. A first step in understanding SARS pathogenesis. J. Pathol. 203, 631-637 (2004).

71. To, K. F. \& Lo, A. W. Exploring the pathogenesis of severe acute respiratory syndrome (SARS): the tissue distribution of the coronavirus (SARS-CoV) and its putative receptor, angiotensin-converting enzyme 2 (ACE2). J. Pathol. 203, 740-743 (2004).

72. Lin, W. et al. Association between detectable SARS-COV-2 RNA in anal swabs and disease severity in patients with coronavirus disease 2019. J. Med. Virol. 93, 794-802 (2021).

73. Ling, Y. et al. Persistence and clearance of viral RNA in 2019 novel coronavirus disease rehabilitation patients. Chin. Med. J. 133, 1039-1043 (2020).

74. Kujawski, S. A. et al. Clinical and virologic characteristics of the first 12 patients with coronavirus disease 2019 (COVID-19) in the United States. Nat. Med. 26, 861-868 (2020).

75. Lo, I. L. et al. Evaluation of SARS-CoV-2 RNA shedding in clinical specimens and clinical characteristics of 10 patients with COVID-19 in Macau. Int. J. Biol. Sci. 16 1698-1707 (2020).

76. Young, B. E. et al. Epidemiologic features and clinical course of patients infected with SARS-CoV- 2 in Singapore. JAMA 323, 1488-1494 (2020).

77. Hua, C. Z. et al. Epidemiological features and viral shedding in children with SARS-CoV-2 infection. J. Med. Virol. 92, 2804-2812 (2020).

78. Han, M. S. et al. Viral RNA load in mildly symptomatic and asymptomatic children with COVID-19, Seoul. Emerg. Infect. Dis. J. 26, 2497-2499 (2020)

79. $\mathrm{Xu}, \mathrm{Y}$. et al. Characteristics of pediatric SARS-CoV-2 infection and potential evidence for persistent fecal viral shedding. Nat. Med. 26, 502-505 (2020)

80. Liu, P. et al. Dynamic surveillance of SARS-CoV-2 shedding and neutralizing antibody in children with COVID-19. Emerg. Microbes Infect. 9, 1254-1258 (2020).

81. Cai, J. et al. A case series of children with 2019 novel coronavirus infection: clinical and epidemiological features. Clin. Infect. Dis. 71, 1547-1551 (2020)

82. Xing, Y. H. et al. Prolonged viral shedding in feces of pediatric patients with coronavirus disease 2019. J. Microbiol. Immunol. Infect. 53, 473-480 (2020).

83. Wu, Y. et al. Prolonged presence of SARS-CoV-2 viral RNA in faecal samples. Lancet Gastroenterol. Hepatol. 5, 434-435 (2020).

84. Chen, Y. et al. The presence of SARS-CoV-2 RNA in the feces of COVID-19 patients. J. Med. Virol. 92 833-840 (2020).

85. Kim, S. E. et al. Viral load kinetics of SARS-CoV-2 infection in saliva in Korean patients: a prospective multi-center comparative study. J. Korean Med. Sci. 35, e287 (2020).

86. Zheng, S. et al. Viral load dynamics and disease severity in patients infected with SARS-CoV-2 in Zhejiang province, China, January-March 2020 retrospective cohort study. BMJ 369, m 1443 (2020).

87. Walsh, K. A. et al. SARS-CoV-2 detection, viral load and infectivity over the course of an infection. J. Infect. 81, 357-371 (2020)

88. Wölfel, R. et al. Virological assessment of hospitalized patients with COVID-2019. Nature 581, 465-469 (2020).

89. Zhang, Y. et al. Isolation of 2019-nCoV from a stool specimen of a laboratory-confirmed case of the coronavirus disease 2019 (COVID-19). China CDC Wkly. 2, 123-124 (2020).
90. Wang, W. et al. Detection of SARS-CoV-2 in different types of clinical specimens. JAMA 323, 1843-1844 (2020).

91. Xiao, F. et al. Infectious SARS-CoV-2 in feces of patient with severe COVID-19. Emerg. Infect. Dis. 26, 1920-1922 (2020).

92. Zhou, J. et al. Infection of bat and human intestinal organoids by SARS-CoV-2. Nat. Med. 26, 1077-1083 (2020).

93. Han, Y. et al. Identification of SARS-CoV-2 inhibitors using lung and colonic organoids. Nature 589 , 270-275 (2021).

94. Lucas, C. et al. Longitudinal analyses reveal immunological misfiring in severe COVID-19. Nature 584, 463-469 (2020)

95. Huang, C. et al. Clinical features of patients infected with 2019 novel coronavirus in Wuhan, China. Lancet 395, 497-506 (2020)

96. Xu, Z. et al. Pathological findings of COVID-19 associated with acute respiratory distress syndrome. Lancet Respir. Med. 8, 420-422 (2020).

97. Magro, F. et al. Comparison of different histological indexes in the assessment of UC activity and their accuracy regarding endoscopic outcomes and faecal calprotectin levels. Gut 68, 594-603 (2019).

98. Jeffery, V., Goldson, A. J., Dainty, J. R., Chieppa, M. \& Sobolewski, A. IL-6 signaling regulates small intestinal crypt homeostasis. J. Immunol. 199, 304-311 (2017)

99. Grivennikov, S. et al. IL-6 and Stat3 are required for survival of intestinal epithelial cells and development of colitis-associated cancer. Cancer Cell 15, 103-113 (2009).

100. Dann, S. M. et al. IL-6-dependent mucosal protection prevents establishment of a microbial niche for attaching/effacing lesion-forming enteric bacterial pathogens. J. Immunol. 180, 6816-6826 (2008).

101. Xu, X. et al. Effective treatment of severe COVID-19 patients with tocilizumab. Proc. Natl Acad. Sci. USA 117, 10970-10975 (2020).

102. Luo $\mathrm{P}$ et al Tocilizumab treatment in COVID-19: a single center experience. J. Med. Virol. 92, 814-818 (2020)

103. Stone, J. H. et al. Efficacy of tocilizumab in patients hospitalized with covid-19. N. Engl. J. Med. 383 2333-2344 (2020).

104. Salama, C. et al. Tocilizumab in patients hospitalized with covid-19 pneumonia. N. Engl. J. Med. 384 20-30 (2021).

105. Hermine, O. et al. Effect of tocilizumab vs usual care in adults hospitalized with COVID-19 and moderate or severe pneumonia: a randomized clinical trial. JAMA Intern. Med. 181, 32-40 (2021)

106. Zhu, S. et al. NIrp9b inflammasome restricts rotavirus infection in intestinal epithelial cells. Nature $\mathbf{5 4 6}$ 667-670 (2017).

107. Elinav, E. et al. NLRP6 inflammasome regulates colonic microbial ecology and risk for colitis. Cell 145, 745-757 (2011).

108. Wang, P. et al. Nlrp6 regulates intestinal antiviral innate immunity. Science 350, 826-830 (2015)

109. Huang, K. J. et al. An interferon-gamma-related cytokine storm in SARS patients. J. Med. Virol. 75, 185-194 (2005)

110. Yang, Y. et al. Exuberant elevation of IP-10, MCP-3 and IL-1 ra during SARS-CoV-2 infection is associated with disease severity and fatal outcome. Preprint at medRxiv https://doi.org/10.1101/2020.03.02. 20029975 (2020)

111. Pu, Q. et al. Interaction among inflammasome, autophagy and non-coding RNAs: new horizons for drug. Precis. Clin. Med. 2, 166-182 (2019).

112. Siegmund, B. et al. Neutralization of interleukin-18 reduces severity in murine colitis and intestinal IFN-gamma and TNF-alpha production. Am. J. Physiol. Regul. Integr. Comp. Physiol. 281, R1264-R1273 (2001).

113. Monteleone, G. et al. Bioactive IL-18 expression is up-regulated in Crohn's disease. J. Immunol. 163, 143-147 (1999)

114. Pizarro, T. T. et al. IL-18, a novel immunoregulatory cytokine, is up-regulated in Crohn's disease: expression and localization in intestinal mucosal cells. J. Immunol. 162, 6829-6835 (1999).

115. Nold, M. F. et al. IL-37 is a fundamental inhibitor of innate immunity. Nat. Immunol. 11, 1014-1022 (2010).

116. Gabay, C. et al. Open-label, multicentre, dose-escalating phase II clinical trial on the safety and efficacy of tadekinig alfa (IL-18BP) in adult-onset Still's disease. Ann. Rheum. Dis. 77, 840-847 (2018).
117. Yildiz, S., Mazel-Sanchez, B., Kandasamy, M., Manicassamy, B. \& Schmolke, M. Influenza A virus infection impacts systemic microbiota dynamics and causes quantitative enteric dysbiosis. Microbiome $\mathbf{6}$, 9 (2018).

118. Hanada, S., Pirzadeh, M., Carver, K. Y. \& Deng, J. C. Respiratory viral infection-induced microbiome alterations and secondary bacterial pneumonia. Front. Immunol. 9, 2640 (2018).

119. Zuo, T. et al. Alterations in gut microbiota of patients with COVID-19 during time of hospitalization. Gastroenterology 159, 944-955.e8 (2020).

120. Geva-Zatorsky, N. et al. Mining the human gut microbiota for immunomodulatory organisms. Cell 168, 928-943.e11 (2017).

121. Zhang, W. \& Zhu, S. Gut metabolites: make orphans adopted. Precis. Clin. Med. 2, 87-89 (2019).

122. Bilotta, A. J. \& Cong, Y. Gut microbiota metabolite regulation of host defenses at mucosal surfaces: implication in precision medicine. Precis. Clin. Med. 2, 110-119 (2019).

123. Haase, S., Haghikia, A., Wilck, N., Müller, D. N. \& Linker, R. A. Impacts of microbiome metabolites on immune regulation and autoimmunity. Immunology 154, 230-238 (2018).

124. Antunes, K. H. et al. Microbiota-derived acetate protects against respiratory syncytial virus infection through a GPR43-type 1 interferon response. Nat. Commun. 10, 3273 (2019)

125. Trompette, A. et al. Dietary fiber confers protection against flu by shaping Ly6c patrolling monocyte hematopoiesis and $\mathrm{CD}^{+} \mathrm{T}$ cell metabolism. Immunity 48, 992-1005.e8 (2018)

126. Chu, H. et al. Comparative tropism, replication kinetics, and cell damage profiling of SARS-CoV- 2 and SARS-CoV with implications for clinical manifestations, transmissibility, and laboratory studies of COVID-19: an observational study. Lancet Microbe 1, e 14-e23 (2020).

127. Zang, R. et al. TMPRSS2 and TMPRSS4 promote SARS-CoV-2 infection of human small intestinal enterocytes. Sci. Immunol. 5, eabc3582 (2020).

128. Lamers, M. M. et al. SARS-CoV-2 productively infects human gut enterocytes. Science 369, 50-54 (2020).

129. Ding, S. et al. STAG2 deficiency induces interferon responses via cGAS-STING pathway and restricts virus infection. Nat. Commun. 9, 1485 (2018).

130. Lau, S. K. et al. Severe acute respiratory syndrome coronavirus-like virus in Chinese horseshoe bats. Proc. Natl Acad. Sci. USA 102, 14040-14045 (2005).

131. Ge, X. Y. et al. Isolation and characterization of a bat SARS-like coronavirus that uses the ACE2 receptor. Nature 503, 535-538 (2013).

132. Wan, Y., Shang, J., Graham, R., Baric, R. S. \& Li, F. Receptor recognition by the novel coronavirus from Wuhan: an analysis based on decade-long structural studies of SARS coronavirus. J. Virol. 94, e00127-20 (2020).

133. Sun, S. H. et al. A mouse model of SARS-CoV-2 infection and pathogenesis. Cell Host Microbe 28. 124-133.e4 (2020).

134. Kim, Y. I. et al. Infection and rapid transmission of SARS-CoV-2 in ferrets. Cell Host Microbe 27 , 704-709.e2 (2020)

135. Munster, V. J. et al. Respiratory disease in rhesus macaques inoculated with SARS-CoV-2. Nature 585 268-272 (2020).

136. Deng, W. et al. Primary exposure to SARS-CoV-2 protects against reinfection in rhesus macaques. Science 369, 818-823 (2020).

137. Sia, S. F. et al. Pathogenesis and transmission of SARS-CoV-2 in golden hamsters. Nature $\mathbf{5 8 3}$ 834-838 (2020).

138. Bao, L. et al. The pathogenicity of SARS-CoV-2 in hACE2 transgenic mice. Nature 583, 830-833 (2020).

139. Shi, J. et al. Susceptibility of ferrets, cats, dogs, and other domesticated animals to SARS-coronavirus 2 Science 368, 1016-1020 (2020).

140. Hassan, A. O. et al. A SARS-CoV-2 infection model in mice demonstrates protection by neutralizing antibodies. Cell 182, 744-753.e4 (2020).

141. Richard, M. et al. SARS-CoV-2 is transmitted via contact and via the air between ferrets. Nat. Commun 11, 3496 (2020)

142. Chan, J. F. et al. Simulation of the clinical and pathological manifestations of coronavirus disease 2019 (COVID-19) in golden Syrian hamster model: implications for disease pathogenesis and transmissibility. Clin. Infect. Dis. 71, 2428-2446 (2020). 
143. Zhou, J. et al. Human intestinal tract serves as an alternative infection route for Middle East respiratory syndrome coronavirus. Sci. Adv. 3, eaao4966 (2017).

144. Rockx, B. et al. Comparative pathogenesis of COVID-19, MERS, and SARS in a nonhuman primate model. Science 368, 1012-1015 (2020).

145. Jiao, L. et al. The gastrointestinal tract is an alternative route for SARS-CoV-2 infection in a nonhuman primate model. Gastroenterology https://doi.org/10.1053/ j.gastro.2020.12.001 (2020)

146. Conrad, K., Roggenbuck, D. \& Laass, M. W. Diagnosis and classification of ulcerative colitis. Autoimmun. Rev. 13, 463-466 (2014).

147. CDC. How COVID-19 spreads. CDC https://www.cdc. gov/coronavirus/2019-ncov/about/transmission.htm (2020).

148. Offord, C. How COVID-19 is spread. The Scientist https://www.the-scientist.com/news-opinion/ how-covid-19-is-spread-67143 (2020).

149. Hong Kong Government. WHO Environmental Health Team reports on Amoy Gardens. Hong Kong Government https://www.info.gov.hk/gia/general/ 200305/16/0516114.htm (2003).

150. Kang, M. et al. Probable evidence of fecal aerosol transmission of SARS-CoV-2 in a high-rise building Ann. Int. Med. 173, 974-980 (2020).

151. Bushman, F. D., McCormick, K. \& Sherrill-Mix, S. Virus structures constrain transmission modes. Nat. Microbiol. 4, 1778-1780 (2019).

152. Hirose, R. et al. Mechanism of human influenza virus RNA persistence and virion survival in feces: mucus protects virions from acid and digestive juices. J. Infect. Dis. 216, 105-109 (2017).

153. Kalantzi, L. et al. Characterization of the human upper gastrointestinal contents under conditions simulating bioavailability/bioequivalence studies. Pharm. Res. 23, 165-176 (2006).

154. Jantratid, E., Janssen, N., Reppas, C. \& Dressman, J. B. Dissolution media simulating conditions in the proximal human gastrointestinal tract: an update. Pharm. Res. 25, 1663-1676 (2008)

155. Chan, K. H. et al. Factors affecting stability and infectivity of SARS-CoV-2. J. Hosp. Infect. 106, 226-231 (2020)

156. Wurtzer, S. et al. Evaluation of lockdown impact on SARS-CoV-2 dynamics through viral genome quantification in Paris wastewaters. Preprint at medRxiv https://doi.org/10.1101/2020.04.12.20062679 (2020).
157. Wu, F. et al. SARS-CoV-2 titers in wastewater are higher than expected from clinically confirmed cases. mSystems 5, e00614-20 (2020).

158. Nemudryi, A. et al. Temporal detection and phylogenetic assessment of SARS-CoV-2 in municipal wastewater. Cell Rep. Med. 1, 100098 (2020).

159. Ahmed, W. et al. First confirmed detection of SARS-CoV-2 in untreated wastewater in Australia: a proof of concept for the wastewater surveillance of COVID-19 in the community. Sci. Total. Environ. 728, 138764 (2020)

160. Pang, X. et al. Cold-chain food contamination as the possible origin of COVID-19 resurgence in Beijing. Natl Sci. Rev. 7, 1864-1864 (2020).

161. Gou, W. et al. Gut microbiota may underlie the predisposition of healthy individuals to COVID-19. Preprint at medRxiv https://doi.org/10.1101/ 2020.04.22.20076091 (2020).

162. Fagarasan, S. \& Honjo, T. Intestinal IgA synthesis: regulation of front-line body defences. Nat. Rev. Immunol. 3, 63-72 (2003).

163. Gutzeit, C., Magri, G. \& Cerutti, A. Intestinal IgA production and its role in host-microbe interaction. Immunol. Rev. 260, 76-85 (2014).

164. Tao, W. et al. Re-detectable positive SARS-CoV-2 RNA tests in patients who recovered from COVID-19 with intestinal infection. Protein Cell https://doi.org/10.1007/ s13238-020-00778-8 (2020).

165. Sterlin, D. et al. IgA dominates the early neutralizing antibody response to SARS-CoV-2. Sci. Transl. Med. 13, eabd2223 (2021).

166. Ma, H. et al. Serum IgA, IgM, and IgG responses in COVID-19. Cell Mol. Immunol. 17, 773-775 (2020).

167. Zhang, Z. et al. Potential role of aberrant mucosa immune response to SARS-CoV-2 in pathogenesis of IgA nephropathy. Preprint at medRxiv https://doi.org/ 10.1101/2020.12.11.20247668 (2020).

168. Mehan, A., Venkatesh, A. \& Girish, M. COVID-19. should oral vaccination strategies be given more consideration? Ther. Adv. Vaccines Immunother. 8 , 2515135520946503 (2020).

169. Moreno-Fierros, L., García-Silva, I. \& Rosales-Mendoza, S. Development of SARS-CoV-2 vaccines: should we focus on mucosal immunity? Expert Opin. Biol. Ther. 20, 831-836 (2020).

170. Lu, X. et al. SARS-CoV-2 infection in children. N. Engl. J. Med. 382, 1663-1665 (2020).

171. Fakiri, K. E., Nassih, H., Sab, I. A., Draiss, G. \& Bouskraoui, M. Epidemiology and clinical features of coronavirus disease 2019 in Moroccan children. Indian Pediatr. 57, 808-810 (2020).

172. de Ceano-Vivas, M. et al. SARS-CoV-2 infection in ambulatory and hospitalised Spanish children. Arch. Dis. Child. 105, 808-809 (2020).

173. Mahmoudi, S. et al. The coronavirus disease 2019 (COVID-19) in children: a study in an Iranian Children's Referral Hospital. Infect. Drug Resist. 13, 2649-2655 (2020).

174. CDC COVID-19 Response Team. Coronavirus disease 2019 in children - United States, February 12-April 2, 2020. MMWR Morb. Mortal. Wkly. Rep. 69, 422-426 (2020)

175. Parri, N., Lenge, M. \& Buonsenso, D. Children with COVID-19 in pediatric emergency departments in Italy. N. Engl. J. Med. 383, 187-190 (2020).

\section{Acknowledgements}

The authors thank Z. G. Tian, H. M. Wei, R. B. Zhou, T. C. Jin, X. L. Ma, K. G. Zhang, J. P. Weng, Y. C. Wang and T. Xue from the University of Science and Technology of China, China, for discussion and comments. The authors are supported by a grant from the Strategic Priority Research Program of the Chinese Academy of Sciences (XDB29030101, S.Z.), National Key R\&D Program of China (2018YFA0508000, S.Z.) and National Natural Science Foundation of China (81822021, $82061148013,91842105,31770990,81821001$, S.Z.). R.A.F. is an investigator of the Howard Hughes Medical Institute.

\section{Author contributions}

All authors contributed equally to discussion of content. M.G. S.Z. and W.T. wrote the article. S.Z. and R.A.F. reviewed/edited the manuscript before submission.

\section{Competing interests}

The authors declare no competing interests.

\section{Peer review information}

Nature Reviews Gastroenterology \& Hepatology thanks J. F. W. Chan, S. Perlman and the other, anonymous, reviewer(s) for their contribution to the peer review of this work.

\section{Publisher's note}

Springer Nature remains neutral with regard to jurisdictional claims in published maps and institutional affiliations.

(C) Springer Nature Limited 2021 